\title{
Computer-aided design of ionic liquids for hybrid process schemes
}

Chen, Yuqiu; Koumaditi, Evangelia; Gani, Rafiqul; Kontogeorgis, Georgios M.; Woodley, John M.

\section{Published in:}

Computers \& Chemical Engineering

Link to article, DOI:

10.1016/j.compchemeng.2019.106556

Publication date:

2019

Document Version

Peer reviewed version

Link back to DTU Orbit

Citation (APA):

Chen, Y., Koumaditi, E., Gani, R., Kontogeorgis, G. M., \& Woodley, J. M. (2019). Computer-aided design of ionic liquids for hybrid process schemes. Computers \& Chemical Engineering, 130, [106556].

https://doi.org/10.1016/j.compchemeng.2019.106556

\section{General rights}

Copyright and moral rights for the publications made accessible in the public portal are retained by the authors and/or other copyright owners and it is a condition of accessing publications that users recognise and abide by the legal requirements associated with these rights.

- Users may download and print one copy of any publication from the public portal for the purpose of private study or research.

- You may not further distribute the material or use it for any profit-making activity or commercial gain

- You may freely distribute the URL identifying the publication in the public portal 


\title{
Computer-Aided Design of Ionic Liquids for Hybrid Process Schemes
}

\author{
Yuqiu Chen a, Evangelia Koumaditi a,b, Rafiqul Gani ${ }^{\text {c,d }}$, Georgios M. Kontogeorgis a \\ John M. Woodley ${ }^{\text {a,* }}$ \\ ${ }^{a}$ Department of Chemical and Biochemical Engineering, Technical University of Denmark \\ DK-2800 Lyngby, Denmark \\ b present address: ORS Consulting, Jåttåvågen 7, 4020 Stavanger, Norway \\ c PSE for SPEED, Skyttemosen 6, DK-3450 Allerod, Denmark \\ ${ }^{\mathrm{d}}$ College of Control Science and Engineering, Zhejiang University, Hangzhou 310027, China \\ *Corresponding author. Tel.: +45 45252885. E-mail address: jw@kt.dtu.dk (J.M. Woodley)
}

\begin{abstract}
Hybrid process schemes that combine two (or more) units operating at their highest process efficiencies to perform one (or more) process tasks are considered as potentially innovative and sustainable processing options. Additionally, Ionic liquids (ILs), as well as certain organic chemicals, are good candidates for use as solvents in hybrid schemes that can replace energy-intensive processing steps. As successful design of solvent-based hybrid schemes depends on the specific properties of the solvent used, a computer-aided ionic liquid design (CAILD) toolbox was added to an existing tool for computer-aided molecular design for solvent selection-design. Promising IL solvent candidates were first identified through the formulation and solution of mixed-integer nonlinear programming (MINLP) problems for CAILD and were then further evaluated in the process simulation design stage, where the process variables were optimized by means of trade-off and sensitivity analysis. In order to understand and develop model-based hybrid reaction systems, a dynamic model that describes the behavior of the reaction system has been developed. Based on a wide range of collected experimental data, parameters of sub-models, used to calculate the temperature-dependent properties of ILs, are regressed for the purpose of process simulation. Consequently, a hybrid process design method combining CAILD and process design-simulation to identify the optimal IL and its corresponding hybrid process specifications has been proposed. The application of this design method has been illustrated through case studies including the separation of aqueous solutions using an IL-based hybrid distillation scheme and the bio-oxidation of alcohols using a hybrid reaction-separation scheme with continuous product removal.
\end{abstract}

Keywords: Hybrid process schemes, ionic liquids, CAILD, process intensification

\begin{tabular}{|ll|}
\hline Abbreviations & \\
Groups for ionic liquids & \\
$\mathrm{CH}_{3}$ & methyl \\
$\mathrm{CH}_{2}$ & methylene \\
$\mathrm{dmN}$ & dimethyl ammonium \\
$1,3-\mathrm{dmIm}(+)$ & 1,3 -dimethylimidazolium \\
$1,2,3-\mathrm{tmIm}(+)$ & $1,2,3$-trimethylimidazolium \\
$1-\mathrm{mPy}(+)$ & 1 -methylpyridinium \\
$1,1-\mathrm{dmPyr}(+)$ & 1,1 -dimethylpyrrolidinium \\
$\mathrm{Am}(1) 111(+)$ & Tetramethyl ammonium \\
$1,1,1,1 \mathrm{Ph}(+)$ & Tetramethyl phosphonium \\
$\mathrm{TDPh}(+)$ & Trihexyl tetradecyl phosphonium \\
$1,1-\mathrm{dmPip}(+)$ & 1,1 -dimethylpiperidinium \\
\hline
\end{tabular}




\begin{tabular}{|ll|}
\hline$\left[\mathrm{Tf}_{2} \mathrm{~N}\right]^{-}$ & bis(trifluoromethanesulfonyl) amide \\
{$\left[\mathrm{BF}_{4}\right]^{-}$} & tetrafluoroborate \\
{$\left[\mathrm{PF}_{6}\right]^{-}$} & hexafluorophosphate \\
{$[\mathrm{Cl}]^{-}$} & chloride \\
{$[\mathrm{Ac}]^{-}$} & acetate \\
{$\left[\mathrm{MeSO}_{4}\right]^{-}$} & methyl sulfate \\
{$\left[\mathrm{EtSO}_{4}\right]^{-}$} & ethyl sulfate \\
{$\left[\mathrm{CF}_{3} \mathrm{SO}_{3}\right]^{-}$} & trifluoromethanesulfonate \\
{$\left[\mathrm{Br}^{-}\right.$} & bromide \\
{$\left[\mathrm{CF}_{3} \mathrm{COO}\right]^{-}$} & trifluoroacetate \\
{$\left[\mathrm{N}(\mathrm{CN})_{2}\right]^{-}$} & dicyanamide \\
{$\left[\mathrm{C}(\mathrm{CN})_{3}\right]^{-}$} & tricyanomethanide \\
{$\left[\mathrm{B}(\mathrm{CN})_{4}\right]^{-}$} & tetracyanoborate \\
{$\left[\mathrm{AlCl}_{4}\right]^{-}$} & tetrachloroalluminate \\
{$\left[\mathrm{InCl}_{4}\right]^{-}$} & tetrachloroindate \\
{$[\mathrm{DMP}]^{-}$} & dimethylphosphate \\
{$[\mathrm{DEP}]^{-}$} & diethyl phosphate \\
{$\left[\mathrm{FeCl}_{4}\right]^{-}$} & tetrachloroironate \\
{$\left[\mathrm{GaCl}_{2}\right]^{-}$} & tetrachlorogallate \\
{$\left[\mathrm{Pf}_{2} \mathrm{~N}\right]^{-}$} & bis(perfluoroethylsulfonyl)imide \\
{$\left[\mathrm{SCN}^{-}\right.$} & thiocyanate \\
{$[\mathrm{eFAP}]^{-}$} & tris(pentafluoroethyl)trifluorophosphate \\
\hline
\end{tabular}

\section{1. Introduction}

2 Solvents and membranes have a wide range of applications in many chemical and related industries.

3 Solvents can be used in a multipurpose role (e.g. reaction medium, extraction solvent) in different 4 processing steps, such as chemical reaction and separation. For example, a reaction step usually 5 carried out in one solvent and the separation step of product recovery requires another solvent or 6 membrane (Papadakis et al., 2016). Therefore, it is advantageous to investigate hybrid schemes that 7 allow solvent or membrane-based processing units operating at their highest efficiencies to perform 8 one or more process tasks.

9 Separation operations to obtain pure products is found in almost all processing routes producing a 10 chemical product, where, the processes involved, like distillation, account for $10-15 \%$ of the world's 11 energy consumption. More energy efficient methods to purify chemicals could greatly reduce carbon 12 dioxide emissions as well as energy cost (Sholl and Lively, 2016). As an important separation 13 technique in chemical process industry, distillation is energy intensive and has the least thermal 14 efficiency (Pellegrino et al., 2004). Nevertheless, nearly $80 \%$ of all vapor-liquid separations are performed by distillation. Its efficiency could significantly contribute to the overall energy consumption in chemical process industries and therefore intensified separation designs that allow energy efficient operation are attractive (Lutze et al., 2010; Babi et al., 2015). One such option is to use hybrid separation schemes, which combine one or more separation techniques operating at their highest energy efficiencies such that a target separation can be achieved at significantly lower energy consumption (Tula et al., 2017).

Bio-reactions, which involve the use of enzymes or living microorganisms for the production of chemical and biochemical substances, may often be carried out under mild conditions, they are highly specific, and involve high reaction rates, therefore, can act as possible alternatives for conventional synthesis routes. However, limitations of biocatalysts mostly related with product and/or substrate inhibition result in low productivity and highly diluted product, which leads in difficult downstream 
separations (Woodley et al., 2008; Van Hecke et al., 2014; Woodley, 2017). In each case, the product needs to be removed as soon as it is formed in order to overcome these constraints and hence increase the product yields of the bio-catalytic process. Generally, recovery and purification stages in bioprocesses require numerous steps, associated with high chemicals and energy consumption, and usually represent $20-60 \%$ of the total cost, and even in some protein synthesis biological process this value may reach $90 \%$ (Martínez-Aragón et al., 2009). For these bioprocesses, hybrid schemes that involve the intensification of the reaction and separation processes are able to lower energy consumption, improve reaction performance as well as reduce the complexity.

9 Together with organic chemicals, ionic liquids (ILs) are being considered as solvents for use in hybrid 10 schemes replacing energy intensive processes. IL-based separation processes are generally energy efficient because of their non-volatility and therefore low energy consuming solvent recovery operations (Seiler et al., 2004; Lei et al., 2014b). For the same reason, membrane-based separations are also promising alternatives for the energy intensive processes (Drioli et al., 2011). However, both IL-based and membrane-based separations are limited to low flux operations due to their operational and economic constraints (e.g. high viscosity or low flux rate, high cost). To overcome such limitations, hybrid schemes are promising innovative and sustainable processing options since processing units (e.g. reactor, column, membrane) are operating at their highest efficiencies in hybrid schemes. For example, reactive distillation (e.g. production of methyl acetate) integrates reaction and separation in a single operating unit resulting in reduced equipment sizes and lower operating cost. Distillation with membrane separation (e.g. n-butane from isobutane) is another example of combining unit operations to achieve lower energy consumption and improve quality of distillation cuts.

Although hybrid schemes have significant potential to contribute the development of the process industries, a main question is when such hybrid schemes can be applied, what characteristics the process problem should have, what the process specification should be and how much improvement can be expected. To find truly innovative and more sustainable solutions, Babi et al. (2015) proposed a computer-aided, multi-level, multi-scale method, where different hybrid schemes can be generated to test if any of them match the desired targets while also satisfying the process specifications. So far, hybrid schemes involving membrane-based separation with distillation (e.g. Figure 2) have been proposed for several separation processes, such as separation of azeotropic mixtures (Rautenbach and Albrecht, 1985; Goldblatt and Gooding, 1986), recovery of olefins (Davis et al., 1993; Moganti et al., 1994; Stephan et al., 1995; Pettersen et al., 1996; Caballero et al., 2009), and the separation of a mixture of alkanes (Tula et al., 2017). In contrast, studies regarding the hybrid process design using ILs as solvents are still scarce.

To achieve the full potential of the hybrid process schemes, the selection of optimal solvents or membranes is of great importance due to fact that different solvents or membranes are usually present with very distinct properties and separation performances, especially for ILs that combine diverse cations, anions and substituents (Holbrey and Seddon, 1999). Currently, ILs are usually selected based on experiments which can be time consuming and cost-intensive since many thousands of ILs may be considered as potential solvents. Therefore, in order to find suitable ILs for specific tasks confidently and rapidly, systematic solvent screening method like computer-aided ionic liquid design (CAILD) is attractive (Karunanithi and Mehrkesh, 2013). To date, studies on CAILD are mainly focusing on the separation of azeotropic mixtures (e.g. ethanol-water, acetone-methanol) and the $\mathrm{CO}_{2}$ capture process, (Valencia-Marquez et al., 2011; Roughton et al., 2012; Karunanithi and Mehrkesh, 2013; Chong et al., 2015; Chong et al., 2016; Farahipour et al., 2016; Chen et al., 2019a). Most recently, CAILD method has been extended to the extractive desulfurization system (EDS) for fuel oils (Song et al., 2018). 
1 Hybrid schemes have potential to contribute significantly to the sustainability of the process industry 2 through the use of CAILD for the optimal design of ILs. This work presents a hybrid process design 3 method combing CAILD with process design-simulation to identify the optimal IL and its 4 corresponding hybrid process specifications. As proof of concept, results from two case studies, i.e. 5 separation of aqueous solutions using hybrid distillation schemes and bio-oxidation of alcohols using 6 hybrid reaction-separation schemes, are presented.

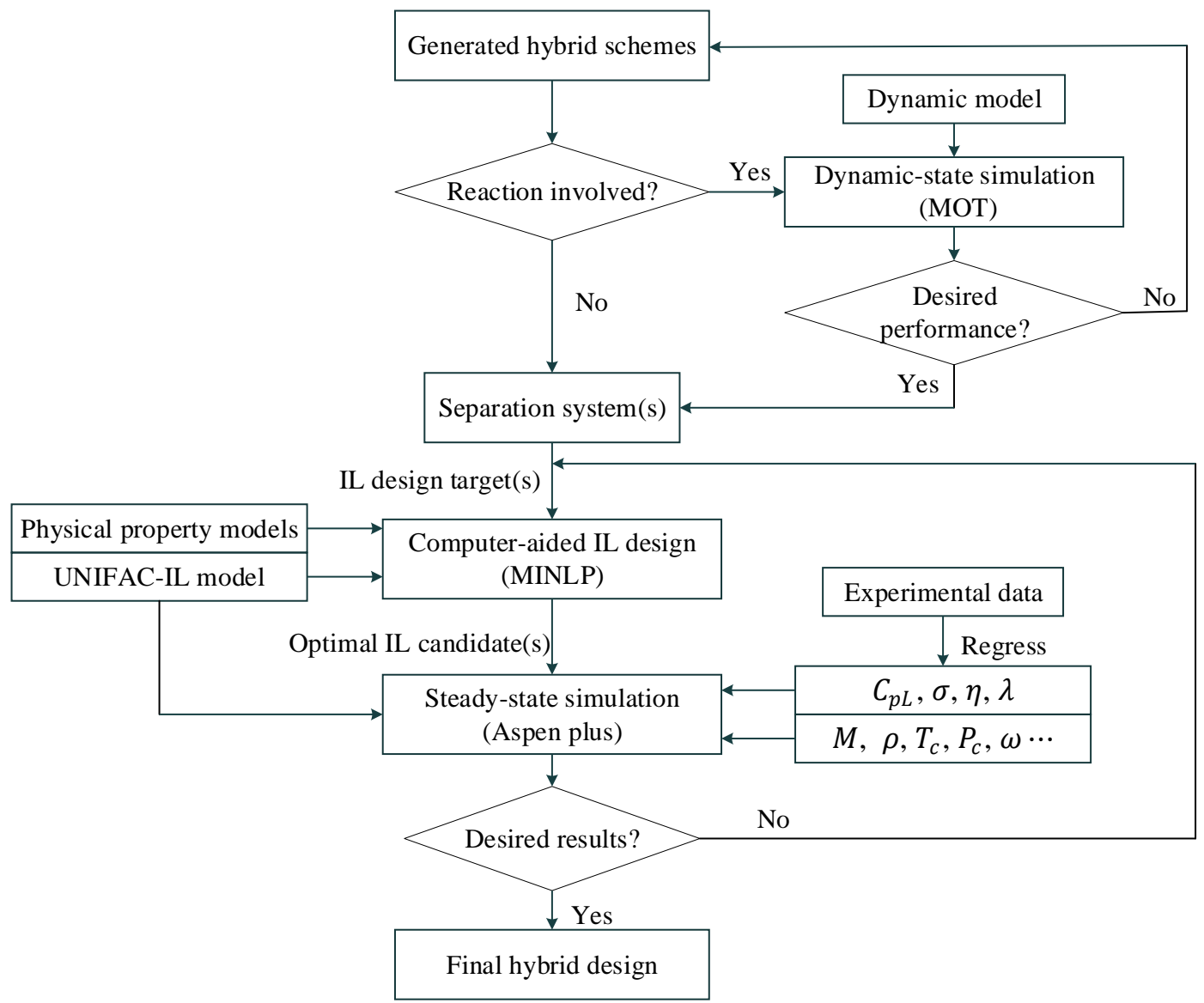

8 Figure 1: Framework of the computer-aided design of ionic liquids for hybrid process schemes

\section{2. Hybrid process design}

In this work, a hybrid process design method that combines CAILD and process design-simulation to identify the optimal IL and its corresponding hybrid process specifications has been proposed (see Figure 1). First, hybrid schemes that have the potential to satisfy the demands of lower energy consumption and/or improve the reaction performance (for biochemical processes) are generated. For the hybrid schemes involving reaction process, a dynamic-state simulation should be performed first to evaluate the reaction performance. The design step can go to the downstream separations if the desired performance is achieved, otherwise the hybrid schemes should be regenerated. Second, based on the IL design target(s) for separation system(s) in the generated hybrid schemes, CAILD including the constraints of IL structure, thermodynamic and physical properties is employed to the optimal design of ILs, where UNIFAC-IL model and physical property models are introduced as the property prediction models. Third, optimal IL candidates identified from the solution of the MINLP-based CAILD problems are further evaluated by means of steady-state simulation in ASPEN Plus, in which the information of thermodynamic model, physical and critical properties of ILs are provided. Among this information, sub-models of four temperature-dependent properties (i.e. $C_{p L}, \sigma, \eta, \lambda$ ) are regressed based on a large number of collected experimental data in this work. Finally, the final hybrid process 
design can be identified if the desired results of the hybrid scheme are achieved, otherwise the design target(s) of IL for CAILD should be adjusted accordingly.

\section{2.1. Generation of Hybrid Schemes}

4 The generation of hybrid schemes is based on the method proposed by Babi et al. (2015). Based on 5 the identified "hot-spots" of a process, design targets for its improvement that overcome the "hot6 spots" are set. Two hybrid schemes, i.e. hybrid distillation with ionic liquid (see Figure 2b) and hybrid 7 reaction-separation scheme (see Figure 3), are investigated and further demonstrated by case studies 8 in this work. In the hybrid distillation scheme, a traditional energy intensive distillation operation is 9 replaced by a combination of not are energy intensive distillation operation with an IL-based extraction distillation. The result is that the same separation is achieved at much lower cost, better environmental impact and reduced waste. In the hybrid reaction-separation scheme, a typical bioreactor operation is combined with solvent-based product recovery giving a higher product yield and avoiding catalyst (enzyme) inhibition.

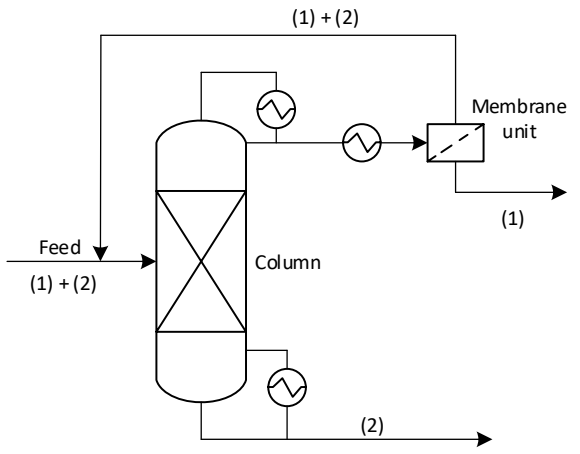

Figure 2a: Hybrid distillation with membrane

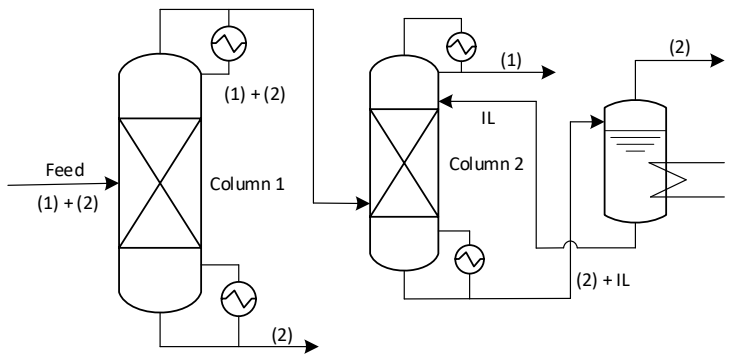

Figure 2b: Hybrid distillation with ionic liquid

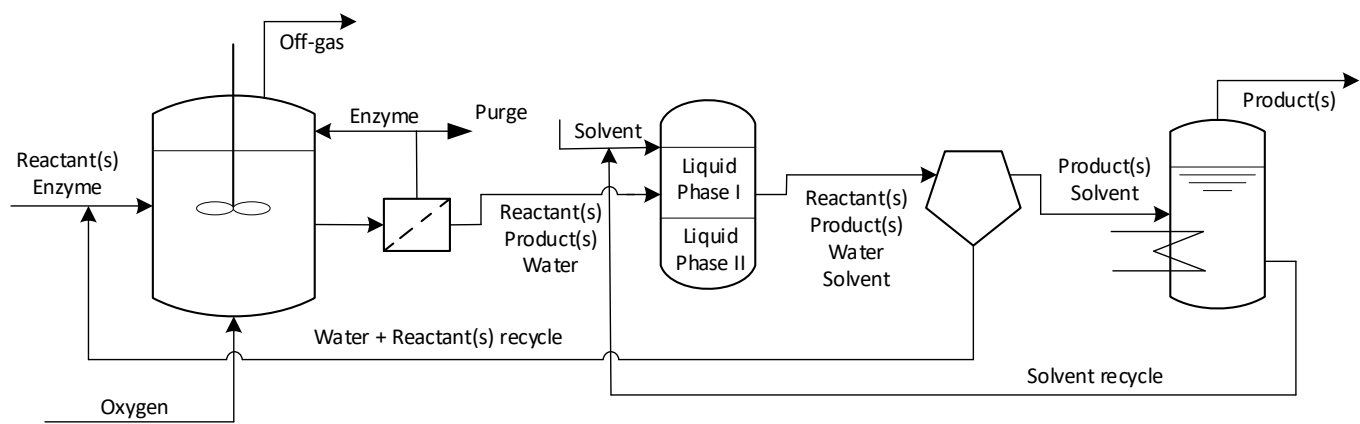

Figure 3: Hybrid bioreaction-separation scheme with continuous product removal

\subsection{Computer-Aided Design of ILs}

To achieve the full potential of the generated hybrid schemes using ILs as solvents, a systematic solvent screening method, CAILD, is considered for the optimal design of ILs in this work. In CAILD, various functional groups (cations, anions and substituents) are combined subject to the constraints of IL structure, thermodynamic and physical properties. The optimal IL candidates can be identified by maximizing or minimizing the objective function (i.e. design target) in CAILD. The CAILD can be summarized as the following MINLP problem

$\max / \min _{z} f_{\text {obj }}(z)$

\section{s.t. IL structural constraints}




\section{thermodynamic property constraints}

\section{physical property constraints}

where $f_{\text {obj }}(z)$ is the objective function and the vector $z$ represents the molecular (IL) structure including the existence and the number of building blocks (cations, anions and substituents). For example, the objective function should be minimized when using Henry's constant as design target for the $\mathrm{CO}_{2}$ capture process, while the objective function should be maximized when using relative volatility as design target for the distillation separation. The CAILD optimization problem has three main constraints: a) IL structural constraints that are introduced to ensure the feasibility (e.g. octet rule, bonding rule) and the complexity (e.g. numbers of substituents) of the IL molecule, the detailed description of these constraints is expressed by Eq.5-11; b) Thermodynamic property constraints that are considered to find more attractive ILs for industrial applications. For example, in a liquid-liquid extraction process, the solubility of the designed IL in raffinate (e.g. aqueous phase) should be constrained to avoid the solvent loss; c) Physical property constraints that are included to ensure the applicability of designed ILs in practical operations. For example, to avoid solidification, the melting point temperature of the designed IL must be at least $5 \mathrm{~K}$ less than the temperature at every point in the whole process, and the viscosity should be relatively low (e.g. less than $0 . .05$ Pa.s) with the consideration of the process operation.

\section{Objective function}

In order to obtain an attractive separation performance of hybrid distillation with IL (see Figure $2 b$ ), a reasonable design target should be set for the CAILD optimization problem. As a measure comparing the vapor pressures of the components in a liquid mixture of chemicals, relative volatility can indicate the ease or difficulty of using distillation to separate the more volatile components from the less volatile components in a mixture. Since the components are to be easily separated from each other with high relative volatility, the maximization of the relative volatility between component (1) and component (2) in the ternary system containing IL is selected as the objective function. In the present work, two types of relative volatility: infinite dilution activity coefficients $\left(\gamma^{\infty}\right)$ based relative volatility $\left(\alpha_{1,2}^{\infty}\right)$ and solvent-to-feed ratio $(\mathrm{S} / \mathrm{F})$ based relative volatility $\left(\alpha_{1,2}^{S / F}\right)$ are considered. They are defined in Equations 2 and 3.

$$
\begin{gathered}
\alpha_{1,2}^{\infty}=\frac{\gamma_{1}^{\infty} P_{1}^{\text {sat }}}{\gamma_{2}^{\infty} P_{2}^{\text {sat }}} \\
\alpha_{1,2}^{S / F}=\frac{\gamma_{1}^{S / F} P_{1}^{\text {sat }}}{\gamma_{2}^{S / F} P_{2}^{\text {sat }}}
\end{gathered}
$$

where $P_{1}^{\text {sat }}$ and $P_{2}^{\text {sat }}$, respectively, represent the saturated pressure of component (1) and component (2). $\gamma_{1}^{\infty}, \gamma_{2}^{\infty}$ are the infinite dilution activity coefficient of component (1) and component (2) while $\gamma_{1}^{S / F}, \gamma_{2}^{S / F}$ are the activity coefficient of component (1) and component (2) with certain S/F, respectively. In a ternary systerm containing IL, the IL interacts differently with the components of the mixture thereby causing their relative volatilities to change, and different ILs generally have different interaction with the components to be separated.

Together with relative volatility, the Hildebrand solubility parameter that can predict solvent-related properties is also considered as design target since compounds with similar solubility parameter are more likely to form a miscible solution (Barton et al., 2017). In this work, a group contribution (GC)based model developed by Roughton et al. (2012) for predicting the Hildebrand solubility parameter of IL $\left(\delta_{I L}\right)$ is used, as given in Eq.4.

$$
\delta_{I L}=\sum_{\mathrm{c}=1}^{k_{\mathrm{c}}} n_{\mathrm{c}} \delta_{\mathrm{c}}+\sum_{\mathrm{a}=1}^{k_{\mathrm{a}}} n_{\mathrm{a}} \delta_{\mathrm{a}}+\sum_{\mathrm{g}=1}^{k_{\mathrm{g}}} n_{\mathrm{g}} \delta_{\mathrm{g}}+b
$$


where parameters $\delta_{\mathrm{c}}, \delta_{\mathrm{a}}$ and $\delta_{\mathrm{g}}$ represent the group contributions from cations, anions and substituents for the Hildebrand solubility parameter while $\delta_{c}, \delta_{\mathrm{a}}$ and $\delta_{\mathrm{g}}$ denote the number of cations, anions and substituents in the IL molecule, respectively. When using Hildebrand solubility parameter as design target in the CAILD optimization problem, the objective function is to minimize the difference between the solubility parameter of IL and the solubility parameter of the entrained component.

When choosing an IL as solvent for the product recovery (liquid-liquid extraction) in the proposed reaction-separation scheme (see Figure 3), its separation performance are generally described by solvent properties at infinite dilution such as distribution coefficient $(D)$ and selectivity $(S)$ (Kumar and Banerjee, 2009; Anantharaj and Banerjee, 2010; Gutiérrez et al., 2012; Karunanithi and Mehrkesh, 2013).

$$
D=\frac{\gamma_{P, H_{2} O}^{\infty} M_{w, H_{2} O}}{\gamma_{P, I L}^{\infty} M_{w, I L}}
$$

$$
S=\frac{\gamma_{R, I L}^{\infty}}{\gamma_{P, I L}^{\infty}}
$$

where $\gamma_{P, H_{2} O}^{\infty}$ is the infinite dilution activity coefficient of product $P$ in the aqueous phase; $\gamma_{P, H_{2} O}^{\infty}$, $\gamma_{R, I L}^{\infty}$ are the infinite dilution activity coefficients of product $P$ and reactant $R$ in the IL phase, respectively; in Eq.1, $M_{w, H_{2} O}$ and $M_{w, I L}$ represent the molecular weights of water and IL, respectively. In this work, $S$ and $\{D \times S\}$, respectively, are considered as the objective function in the CAILD optimization problem and both them should be maximized.

\section{IL structural constraints}

To ensure the feasibility and complexity of designed ILs, A detailed set of constraints proposed by (Karunanithi and Mehrkesh, 2013) is introduced, shown as in Eqs.7-13.

where $C, A, S$ are the sets of cations, anions and substituents, respectively; the cations are represented by the binary variable of $c_{i}$ and the anions are represented by the binary variables of $\alpha_{j}$. The vector $x_{l}$ of binary variables represent the side chains $l$, while the vector $n_{k l}$ of integer variables denotes the number of substituents of type $k$ in the side chain $l$. Group valences of the cations and substituents, respectively, described by vectors of $v_{i}$ and $v_{s l}$. As shown in Eqs.7 and 8, only one cation and one anion is available in each IL molecule. The octet rule that ensures the consistency between the number of side chains and the free valence of the cation is described by Eq.9. Meanwhile, Eqs.10 and 11 are utilized to ensure that any two adjacent groups are not linked by more than one covalent bond. As given in Eqs.12 and 13, minimum and maximum numbers of substituents $n_{S}^{L}, n_{S l}^{L}$ and $n_{S}^{U}, n_{S l}^{U}$ are, respectively, specified to the cation and each side chain $l$ with the consideration of the size and complexity of designed IL candidates.

\section{Thermodynamic property constraints}


To find ILs with attractive process performance, some thermodynamic property constraints are necessary. For the ILs used in hybrid distillation, constraint of relative volatility that ensures the possibility of the separation process should be considered. On the other hand, when IL is selected as the solvent for liquid-liquid extraction in a dilute aqueous solution, the constraints of distribution coefficient, selectivity and solvent loss $(S l)$ should be introduced to the CAILD problem. In this work, $S l$ is described as the following equation

$$
S l=\frac{1}{\gamma_{L, H_{2} O}^{\infty} O}
$$

where $\gamma_{I L, H_{2} O}^{\infty O}$ represents the infinite dilution activity coefficient of solvent (IL) in the aqueous phase.

To predict the thermodynamic behavior of the IL containing system, different types of methods have been introduced and extended. They are can be summarized as conductor-like screening model (COSMO)-based priori thermodynamic methods including COSMO-RS (Klamt, 1995; Klamt et al., 1998; Klamt and Eckert, 2000; Eike et al., 2004; Lei et al., 2007; Gutiérrez et al., 2012) and COSMOSAC (Lin and Sandler, 2002; Lin et al., 2004; Lee and Lin, 2015), equations of state like GCLF and PC-SAFT (Lei et al., 2012b; Dai et al., 2013; Paduszynski et al., 2015) and activity coefficient based methods such as UNIQUAC, NRTL and UNIFAC (Simoni et al., 2008; Santiago et al., 2009; Lei et al., 2010a; Santiago et al., 2010b; Lei et al., 2012a; Lei et al., 2014a; Roughton et al., 2012; Hector and Gmehling, 2014).

In this work, UNIFAC is considered as the thermodynamic method because of its reliable predictions and easy integration with the use of CAILD. Proper decomposition of ILs is required for the application of UNIFAC method, here the decomposition approach where the IL is divided into cation, anion, and substituents separately is employed since it can improve the design space and the flexibility of the CAILD optimization problem (Song et al., 2018).

\section{Physical property constraints}

Properties of ILs (ILs), especially the melting point and the viscosity, are important for the optimal design of ILs. For example, to avoid solidification of the solvent, the melting point temperature $\left(T_{m}\right)$ of the designed IL must be at least $5 \mathrm{~K}$ less than the temperature at every point in the whole process $\left(T_{p}\right)$ while the viscosity $(\eta)$ has significant impact on the process operation. Therefore, constraints ensure the applicability of the designed ILs are added to these two properties (see Eq.15 and 16).

$$
\begin{aligned}
& T_{p}-T_{m}<5(K) \\
& \eta<0.05 \text { (Pa.s) }
\end{aligned}
$$

Several types of methods such as quantum chemistry-based method (Trohalaki et al., 2005; Sun et al., 2006; Palomar et al., 2007; Torrecilla et al., 2009), empirical correlations (Diedenhofen et al., 2007; Jacquemin et al., 2006; Guerrero et al., 2012; Fröba et al., 2010), GC-based methods (Paduszynski and Domanska, 2011; Gardas and Coutinho, 2009; Chen et al., 2019b) and corresponding states principle-based equations (Valderrama and Zarricueta, 2009; Mousazadeh and Faramarzi, 2011) have been developed for the physical property predictions of ILs. Among them, GC-based methods are preferred since it can be easily integrated with the use of CAILD. For this reason, two GC-based estimation methods developed in our previous work (Chen et al., 2019b) are used to calculate $T_{m}$ and $\eta$ of ILs.

\subsection{Process Design-Simulation}

\section{Hybrid distillation with ionic liquid}

As shown in Figure 2b, two separation techniques (a conventional distillation and an IL-based distillation) are combined in the proposed hybrid scheme involving IL-based distillation. Both 
distillations have their regions of efficient operations. For conventional distillation, this should have significant energy savings and for IL-based distillation it reduces the amount of IL and also improves the column operation (e.g. low viscosity). So replacing the part of the separation where conventional distillation has very low driving force (or requires most of the energy) with a IL-based distillation that has higher separation efficiency in this region will ensure both the separation techniques are operating at their high efficiency regions. The hybrid scheme has better energy efficient and economical performance than any of the separation techniques on their own.

To evaluate the process performance of the hybrid distillation scheme using IL identified from the solution of the CAILD problems, detailed process simulations are performed in Aspen Plus. To date, ILs are still not included to the component database in Aspen Plus and therefore they should be defined as pseudo-components. For the purpose of these definition, properties of ILs such as molecular weights, densities and critical properties need to be specified. Likewise, information of the thermodynamic method for the IL containing system is also required.

Critical properties of ILs can be calculated using the fragment contribution-corresponding states method developed by Huang et al. (2013), as following equations $\Delta P_{c, i}$, and $\Delta V_{c, i}$ represent the fragment increments of fragment $i$ for the normal boiling temperature $\left(T_{b}\right)$, critical temperature $\left(T_{c}\right)$, critical pressure $\left(P_{c}\right)$, critical volume $\left(V_{c}\right)$, respectively; $M$ is the molar mass in g.mol ${ }^{-1}$. In Eq.21, $\omega$ is the acentric factor and $P_{b}$ is the atmospheric pressure in bar.

To calculate the temperature-dependent properties such as heat capacity, surface tension, viscosity and thermal conductivity, prediction sub-models of these properties in Aspen Plus (Eqs.22-25) are extracted and further regressed based on a wide range of published experimental data (see Appendix and Supplementary material).

$$
\begin{gathered}
C_{p L}=C_{1 p L}+C_{2 p L} T+C_{3 p L} T^{2}+C_{4 p L} T^{3}+C_{5 p L} / T^{2} \\
\sigma=C_{1 \sigma}+C_{2 \sigma} T+\cdots+C_{10 \sigma} T^{9} \\
\ln \eta=C_{1 \eta}+C_{2 \eta} / T+C_{3 \eta} \ln T+C_{4 \eta} T^{2}+C_{5 \eta} / T^{2} \\
\lambda=C_{1 \lambda}+C_{2 \lambda} T+C_{3 \lambda} T^{2}+C_{4 \lambda} T^{3}+C_{5 \lambda} T^{4}
\end{gathered}
$$

where, $T$ is the absolute temperature in $\mathrm{K}$; heat capacity $C_{p L}\left(\mathrm{~J} \cdot \mathrm{mol}^{-1} \cdot \mathrm{K}^{-1}\right)$, surface tension $\sigma\left(\mathrm{N} \cdot \mathrm{m}^{-1}\right)$, viscosity $\eta$ (Pa.s) and thermal conductivity $\lambda\left(\mathrm{W} . \mathrm{m}^{-1} \cdot \mathrm{K}^{-1}\right)$ can be calculated from their corresponding modeling parameters $C_{m p L}, C_{m \sigma}, C_{m \eta}$ and $C_{m \lambda}(m=1,2,3 \cdots)$, respectively.

As in the design stage of CAILD, UNIFAC is also selected as the thermodynamic method in Aspen Plus for process simulation. In this work, group volume parameters $\left(R_{k}\right)$, surface area parameters $\left(Q_{k}\right)$ as well as interaction parameters $\left(\alpha_{m n}, \alpha_{n m}\right)$ of UNIFAC-IL model are taken from the published works by Wittig et al. (2003) and Roughton et al. (2012). In their work, parameters $R_{k}, Q_{k}$ were 
1 calculated based on the rules of Bondi (Bondi, 1964) and parameters $\alpha_{m n}, \alpha_{n m}$ were regressed on the basis of experimental data containing activity coefficients of different solutes at infinite dilution in various ILs. These parameters were validated by comparing experimental and calculated ternary VLE data of various binary aqueous mixtures (ethanol-water, 1-propanol-water and 2-propanol-water) with different ILs (Roughton et al., 2012).

\section{Hybrid reaction-separation scheme}

7 Hybrid reaction-separation scheme is an intensified process operation where the conversion of the reactant(s) is completed in the reactor and the product recovery is performed externally with a separate loop where separation technique of liquid-liquid extraction is used, as presented in Figure 3. Bioreactions are considered in this hybrid scheme, meaning that the medium of the reactor contains large amounts of water. In liquid-liquid extraction, the solvent should be able to extract the product (s) from the dilute water solution and separate it from the reactants. Meanwhile, the reactant (s) should remain dissolved in the aqueous phase and then recycled back to the reactor after decantation. After liquidliquid extraction, the product (s) and the solvent are further separated in a flash evaporator, where the product s are recovered and the solvent is regenerated. In this case, a heavy solvent with very low volatility and water immiscibility is needed to achieve the separation target and therefore hydrophobic ILs are the potential solvent candidates. CAILD is selected as the solvent screening method and the feasibility of the product recovery with the identified ILs from solution of CAILD problem is evaluated by the liquid-liquid equilibrium (LLE) calculation of the studied IL containing system performed in Aspen Plus.

A dynamic-state simulation is required to evaluate the possibility of improving reaction performance by the continuous product removal from reactor (Figure 4). For this reason, a dynamic model that describes the behavior of the reaction system is developed for the dynamic-state simulation. The model aims to be applicable for any kind of reaction process catalyzed by enzymes with low substrate concentrations and low yields. Aerobic bio-reactions are also taken into consideration in this model and therefore the presence of the vapor phase is due to possible aeriation requirements.

27

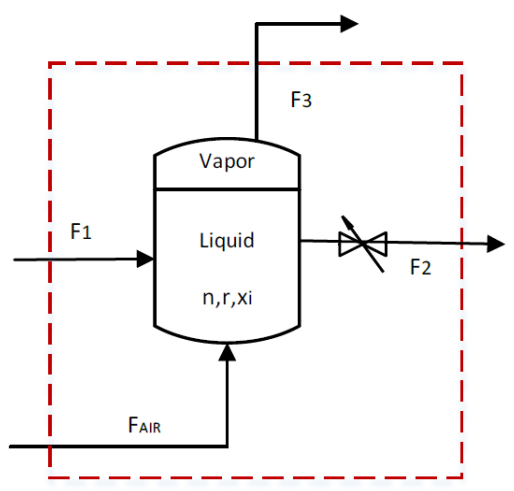

Figure 4: Schematic representation of the modelled reactor

In Figure $4, F_{1}, F_{2}, F_{A I R}$ and $F_{3}$ refer to the inlet and outlet molar flow rates of the liquid $\left(F_{1}, F_{2}\right)$ and the vapor phase $\left(F_{A I R}, F_{3}\right)(\mathrm{kmol} / \mathrm{h})$, respectively. $F_{1}, F_{2}$ can be controlled by adjusting the value in the liquid outlet of the reactor. The dynamic model is expressed as following equations:

$$
\frac{d n_{i}}{d t}=F_{1} x_{1, i}-F_{2} x_{2, i}+\gamma_{i} r-F_{3} y_{i}
$$

$$
F_{3} y_{i}=F_{a i r} y_{i}-\vartheta_{i}^{V} F_{a i r} y_{i}+\vartheta_{i}^{L} n_{i}
$$




$$
\begin{gathered}
x_{1, i}=\frac{f_{1, i}}{F_{1}} \\
x_{2, i}=\frac{n_{i}}{N} \\
y_{i}=\frac{f_{3, i}}{F_{3}} \\
F_{1}=\sum_{i=1}^{N C} f_{1, i} \\
F_{2}=C_{v} h \\
F_{3}=\sum_{i=1}^{N C} f_{3, i} \\
N=\sum_{i=1}^{N C} n_{i} \\
\bar{\rho}=\sum_{i=1}^{N C} \rho_{i} n_{i} \\
h=\frac{N}{\bar{\rho} A} \\
V=h A \\
C_{i}=\frac{n_{i}}{V}
\end{gathered}
$$

where the total number of moles $(N)$ in the reactor is equal to the sum of the moles of each components $i\left(n_{i}\right)$; the molar fraction of component $i$ in the vapor phase $\left(y_{i}\right)$ can be calculated by Eq.30, and the molar fraction of component $i$ in the liquid inlet $\left(x_{1, i}\right)$ and outlet $\left(x_{2, i}\right)$ of the reactor can be calculated by Eq.28 and Eq.29, respectively. $\gamma_{i}$ represents the stoichiometric coefficient of component $i$ and $C_{v}$ describes the value coefficient; $\vartheta_{i}^{V}$ is the coefficient for the reacted gases while $\vartheta_{i}^{L}$ is the removal coefficient of the moles of the liquid compounds. $f_{1, i}, f_{3, i}$ are the inlet molar flow rates of component $i$ in the inlet stream and the vapor outlet, respectively. Based on the ideal mixing rule (Eq.35), the density of the liquid mixture $(\bar{\rho})$ can be calculated from the pure component density $\left(\rho_{i}\right)$; the volume of the liquid $(V)$ is calculated as the product of the cross-sectional area $(A)$ times the level of the liquid $(h)$. The concentrations of the enzyme $\left(C_{E}\right)$ and the oxygen $\left(C_{O}\right)$ are considered to be constant throughout the reaction, while the concentrations of the substrate $\left(C_{S}\right)$ and the product $\left(C_{P}\right)$ change with the time can be calculated by Eq.38.

The equations in this dynamic model are derived from the differential mass balance since the model parameters such as the concentrations of substrate and product are changing over the time. Different reaction systems have different reaction kinetic models and kinetic parameters. Generally, the kinetic model and its corresponding kinetic parameters are developed and regressed from experimental work. In this work, ICAS-MoT (Fedorova et al., 2015) is applied as the process simulator for dynamic-state.

Table 1 summarizes the overall information of the proposed design method for hybrid processes. In the design stage of CAILD, besides the objective function and the constraints of the design problem, thermodynamic method (UNIFAC) and group parameters (e.g. group sets, boundaries of group number) are also included. The variables describing the IL structure are optimized by solving the formulated MINLP problem for CAILD. Subsequently, the optimal IL identified from CAILD and the information of its critical, physical and thermodynamic properties are used in the design stage of process simulation. Meanwhile, process parameters such as feed information, operating conditions are provided as well. The process variables (e.g. column configurations, solvent flowrate) are optimized by means of trade-off and sensitivity analysis. On the other hand, when the IL is selected as the solvent for the liquid-liquid extraction, the LLE calculation of the IL containing system is performed aims to evaluate the possibility of the phase split. In the case of hybrid reaction-separation scheme, a dynamic-state simulation is also needed to evaluate the possibility of improving reaction 
1 performance (e.g. yield, reaction rate) by continuous product removal from reactor. As required, 2 dynamic model describing the behavior of the reaction system, as well as kinetic parameters, reaction 3 conditions etc., should be provided.

4 Table 1: Overall information of the proposed hybrid process design involving IL

\begin{tabular}{|c|c|}
\hline \multicolumn{2}{|l|}{ CAILD (Stage 1) } \\
\hline Objective function & $\begin{array}{l}\text { e.g. } \max \left(\alpha_{1,2}^{\infty}\right) ; \max \left(\alpha_{1,2}^{S / F}\right) ; \min \left(\left|\delta_{I L}-\delta_{2}\right|\right) \\
\max (S) ; \max (\{D \times S\})(\text { Eqs.2-6) }\end{array}$ \\
\hline IL structure constraints & Feasibility (Eqs.7-10), complexity (Eqs.12-13) \\
\hline Thermodynamic property constraints & e.g. $\alpha$ (Eqs.1-2); $S$ (Eq.5); $D$ (Eq.6); Sl (Eq.14) \\
\hline Physical property constraints & $T_{m}, \eta($ Eqs. $15-16)$ \\
\hline Thermodynamic method & UNIFAC \\
\hline Fixed parameters & $C, A, S, n_{S}^{L}, n_{S l}^{L}, n_{S}^{U}, n_{S l}^{U}$ \\
\hline Optimization variables & $c_{i}, a_{j}, x_{l}, v_{i}, v_{k l}, n_{k l}$ \\
\hline \multicolumn{2}{|l|}{ Process design-simulation (Stage 2) } \\
\hline \multicolumn{2}{|l|}{ Steady-state simulation } \\
\hline Optimal IL (Identified from CAILD) & e.g. $\left[\mathrm{C}_{3} \mathrm{mPy}\right]^{+}\left[\mathrm{BF}_{4}\right]^{-} ;\left[\mathrm{C}_{4} \mathrm{mIm}\right]^{+}\left[\mathrm{Tf}_{2} \mathrm{~N}\right]^{-}$ \\
\hline Critical properties & $T_{b}, T_{c}, P_{c}, V_{c}, \omega($ Eqs. $17-21)$ \\
\hline Physical properties & $C_{p L}, \sigma, \eta, \lambda($ Eqs.22-25) \\
\hline Thermodynamic properties & $R_{k}, Q_{k}, \alpha_{m n}, \alpha_{n m}($ UNIFAC-IL model $)$ \\
\hline Process parameters & $\begin{array}{l}\text { Feed information (e.g. flowrate, composition), } \\
\text { operating conditions (e.g. pressure, temperature) }\end{array}$ \\
\hline Optimization variables & $\begin{array}{l}\text { Number of stages, feed stage, reflux ratio, solvent } \\
\text { flowrate }\end{array}$ \\
\hline \multicolumn{2}{|l|}{ Dynamic-state simulation } \\
\hline Dynamic model & Eqs.26-38 \\
\hline Fixed parameters & Kinetic parameters, reaction conditions \\
\hline Performance indicator & Reaction rate, yield \\
\hline
\end{tabular}

\section{Case studies}

\subsection{Separation process of aqueous solutions}

Separation of aqueous solutions is widely encountered in process industries, such as in the separation process of the methanol-water mixture, where the energy requirement increases significantly with respect to the recovery of methanol from 0.98 to 0.998 (mole-based). Likewise, acetone separation from aqueous solution has a similar energy consumption distribution, as shown in Figure 5, where data points of both examples come from the process simulation in Aspen Plus. For both cases, "hotspots" can be identified based on their energy consumption distribution. Considering the significant energy savings potential of using energy efficient process to replace the energy intensive separation task (i.e. remove "hot-spots"), sustainable hybrid distillation designs proposed in this work are promising alternatives for these separation processes.

In the process of methanol separation from aqueous solution, the process task can be defined as follows: a $1000 \mathrm{kmol} . \mathrm{h}^{-1}$ liquid mixture consisting of $20 \mathrm{~mol} \%$ methanol and $80 \mathrm{~mol} \%$ water, to be separated by hybrid distillation with IL so that the methanol composition of distillate from extractive distillation column amounts to $99.8 \mathrm{~mol} \%$. For the case of acetone separation from aqueous solution, we consider a $1000 \mathrm{kmol} . \mathrm{h}^{-1}$ liquid mixture consisting of $20 \mathrm{~mol} \%$ acetone and $80 \mathrm{~mol} \%$ water which is separated by hybrid distillation with IL for meeting the acetone purification of $99.8 \mathrm{~mol} \%$. In this work, IL-based extractive distillation is considered to perform the energy intensive separation task of the process for both cases. Fixed process parameters for the proposed hybrid process are given in Table 2 . 


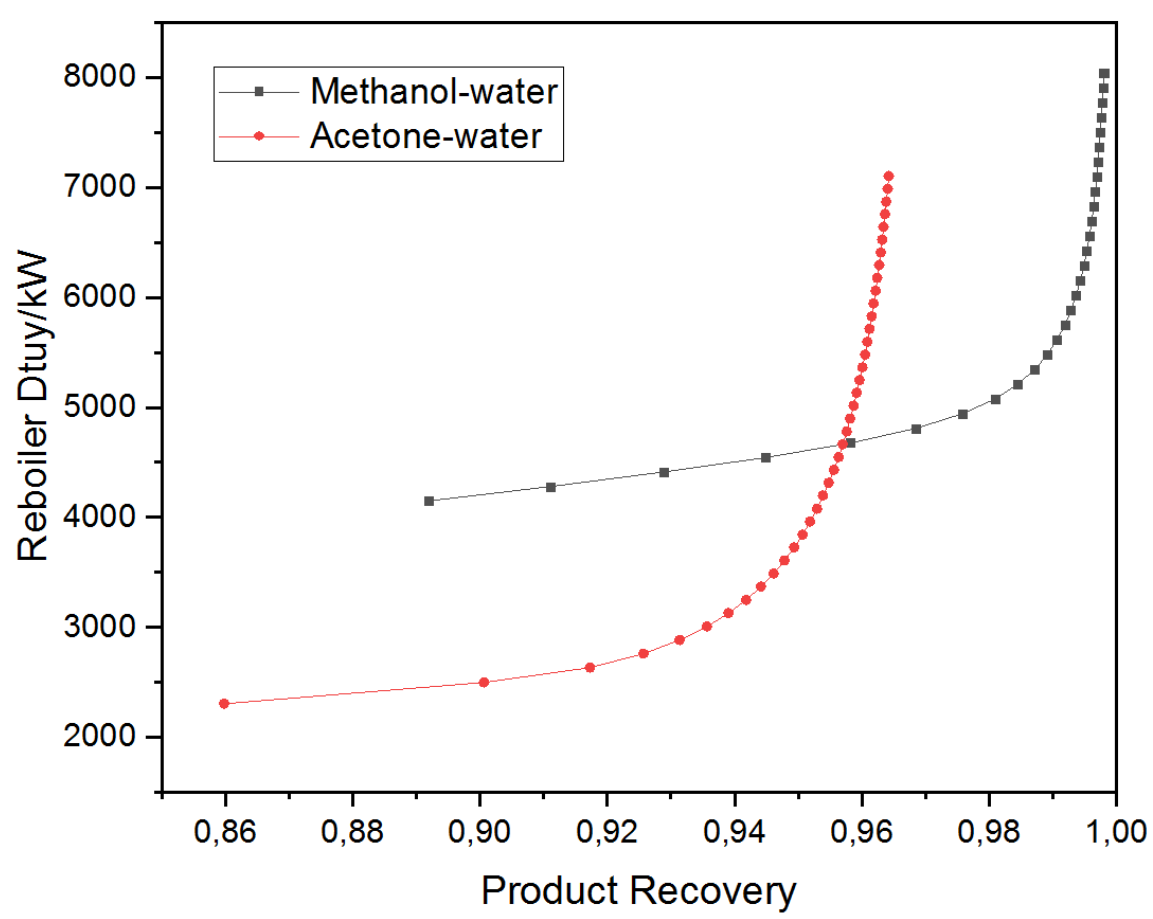

2 Figure 5: Energy consumption distribution in the separation process of aqueous solutions

3 Table 2: Fixed parameters and simulation results of the conventional distillation for the separation 4 process of aqueous solution

\begin{tabular}{lcc}
\hline Fixed parameters & Methanol-water & Acetone-water \\
\hline Feed & & \\
Flow rate & $1000 \mathrm{kmol} / \mathrm{h}$ & $1000 \mathrm{kmol} / \mathrm{h}$ \\
Mole-based composition & $0.2 \mathrm{CH}_{3} \mathrm{OH}, 0.8 \mathrm{H}_{2} \mathrm{O}$ & $0.2\left(\mathrm{CH}_{3}\right)_{2} \mathrm{CO}, 0.8 \mathrm{H}_{2} \mathrm{O}$ \\
Methanol purity & $99.8 \mathrm{~mol} \% \mathrm{CH}_{3} \mathrm{OH}$ & $99.8 \mathrm{~mol} \%\left(\mathrm{CH}_{3}\right)_{2} \mathrm{CO}$ \\
Distillation Column & & \\
Pressure at the top & $1 \mathrm{bar}$ & $1 \mathrm{bar}$ \\
Pressure at the bottom & $1.2 \mathrm{bar}$ & $1.2 \mathrm{bar}$ \\
Number of stages & 20 & 33 \\
Feed stage & 13 & 31 \\
Reflux ratio & 1.95 & 2.95 \\
Reboiler heat duty & $5987 \mathrm{~kW}$ & $7022 \mathrm{~kW}$ \\
& $\left(99.8 \mathrm{~mol} \% \mathrm{CH}{ }_{3} \mathrm{OH}\right)$ & $\left(97 \mathrm{~mol}^{\circ}\left(\mathrm{CH}_{3}\right)_{2} \mathrm{CO}\right)$ \\
\hline
\end{tabular}

5 Table 3: Molecular building blocks for IL design in the case studies of aqueous separation

\begin{tabular}{llllll}
\hline Type & Group & Subgroup & Type & Group & Subgroup \\
\hline Substituents & $\mathrm{CH}_{3}$ & $\mathrm{CH}_{3}$ & Anions & {$\left[\mathrm{Tf}_{2} \mathrm{~N}\right]^{-}$} & {$\left[\mathrm{Tf}_{2} \mathrm{~N}\right]^{-}$} \\
& & $\mathrm{CH}_{2}$ & & {$\left[\mathrm{BF}_{4}\right]^{-}$} & {$\left[\mathrm{BF}_{4}\right]^{-}$} \\
Cations & {$[\mathrm{Im}]^{+}$} & {$[\mathrm{Im}]^{+}$} & & {$\left[\mathrm{PF}_{6}\right]^{-}$} & {$\left[\mathrm{PF}_{6}\right]^{-}$} \\
& & {$[\mathrm{mIm}]^{+}$} & & {$\left[\mathrm{CF}_{3} \mathrm{SO}_{3}\right]^{-}$} & {$\left[\mathrm{CF}_{3} \mathrm{SO}_{3}\right]^{-}$} \\
& {$[\mathrm{Py}]^{+}$} & {$[\mathrm{Py}]^{+}$} & & {$\left[\mathrm{CF}_{3} \mathrm{COO}\right]^{-*}$} & {$\left[\mathrm{CF}_{3} \mathrm{COO}^{-*}\right.$} \\
& & {$[\mathrm{mPy}]^{+}$} & & {$[\mathrm{DMP}]^{-}$} & {$[\mathrm{DMP}]^{-}$} \\
& & & {$[\mathrm{SCN}]^{-*}$} & {$[\mathrm{SCN}]^{-*}$} \\
\hline
\end{tabular}

*NB: Groups only used in the case study of ethanol-water separation 
As shown in Table 3, 2 widely studied 2 substituents, 2 cations and 7 anions were selected as building blocks for the IL design. Table 4 summaries the design information of the MINLP-based CAILD problem in these case studies. The formulated MINLP problem of both examples are solved using deterministic global optimization solvers (LINDOGLOBAL) in the modelling system GAMS.

Table 4: Design information of MINLP-based CAILD problem for the case studies of aqueous separation

\begin{tabular}{|c|c|c|c|c|c|c|}
\hline \multirow[t]{2}{*}{ Case } & \multirow{2}{*}{$\begin{array}{l}\text { Number of } \\
\text { continuous } \\
\text { variables }\end{array}$} & \multirow{2}{*}{$\begin{array}{l}\text { Number } \\
\text { of binary } \\
\text { variables }\end{array}$} & \multirow{2}{*}{$\begin{array}{l}\text { Number } \\
\text { of integer } \\
\text { variables }\end{array}$} & \multicolumn{3}{|c|}{ Number of constraints } \\
\hline & & & & $\begin{array}{l}\text { IL } \\
\text { structure }\end{array}$ & $\begin{array}{l}\text { Thermodynamic } \\
\text { properties }\end{array}$ & $\begin{array}{l}\text { Physical } \\
\text { properties }\end{array}$ \\
\hline $\begin{array}{l}\text { Methanol- } \\
\text { water }\end{array}$ & 195 & 23 & 70 & 60 & 126 & 4 \\
\hline $\begin{array}{l}\text { Acetone- } \\
\text { water }\end{array}$ & 195 & 21 & 70 & 60 & 126 & 4 \\
\hline
\end{tabular}

By solving the MINLP-based CAILD optimization problem (see Equations 1-13) using $\gamma^{\infty}$ based and $\mathrm{S} / \mathrm{F}$ based relative volatility of methanol and water in the ternary system containing IL as objectives, 1-ethylpyridinium tetrafluoroborate $\left(\left[\mathrm{C}_{2} \mathrm{Py}\right]^{+}\left[\mathrm{BF}_{4}\right]^{-}\right)$and 1-ethyl-3-methylpyridinium tetrafluoroborate $\left(\left[\mathrm{C}_{2} \mathrm{mPy}\right]^{+}\left[\mathrm{BF}_{4}\right]^{-}\right)$are selected, respectively; meanwhile, 1-methylimidazolium tetrafluoroborate $\left([\mathrm{mIm}]^{+}\left[\mathrm{BF}_{4}\right]^{-}\right)$is identified as entrainer while using the Hildebrand solubility parameter of ILs $\left(\delta_{I L}\right)$ as design target in the CAILD optimization problem. Similarly, for the separation process of acetone-water mixture, 3-methyl-1-propylpyridinium tetrafluoroborate $\left(\left[\mathrm{C}_{3} \mathrm{mPy}\right]^{+}\left[\mathrm{BF}_{4}\right]^{-}\right)$and 1-methylpyridinium dimethylphosphate $\left(\left[\mathrm{C}_{1} \mathrm{Py}\right]^{+}[\mathrm{DMP}]^{-}\right)$are identified, respectively, using $\gamma^{\infty}$ based relative volatility (or $\delta_{I L}$ ) and $\mathrm{S} / \mathrm{F}$ based relative volatility as design targets. Table 5 provides the model statics from GAMS solution of the MINLP-based CAILD problem and the structures of the generated IL candidates are given by Figure 6 .

Table 5: Model statistics from GAMS solution for the case studies of aqueous separation

\begin{tabular}{llllllll}
\hline Case & $\begin{array}{l}\text { Number of } \\
\text { continuous } \\
\text { variables }\end{array}$ & $\begin{array}{l}\text { Number } \\
\text { of binary } \\
\text { variables }\end{array}$ & $\begin{array}{l}\text { Number } \\
\text { of } \\
\text { equations }\end{array}$ & $\begin{array}{l}\text { Number } \\
\text { of } \\
\text { constraints }\end{array}$ & $\begin{array}{l}\text { Objective } \\
\text { function }\end{array}$ & $\begin{array}{l}\text { Number } \\
\text { of } \\
\text { iterations }\end{array}$ & $\begin{array}{l}\text { CPU } \\
\text { time } \\
(\mathrm{s})\end{array}$ \\
\hline $\begin{array}{l}\text { Methanol- } \\
\text { water }\end{array}$ & 195 & 23 & 191 & 190 & $\alpha_{1,2}^{\infty}$ & 210 & 4 \\
$\begin{array}{l}\text { Acetone- } \\
\text { water }\end{array}$ & 195 & 21 & 191 & 190 & $\alpha_{1,2}^{S / F}$ & 203475 & 24 \\
\hline
\end{tabular}

As shown in Figure 2b, two distillation columns and a flash unit are included in the proposed hybrid distillation with IL. Column 1 is used as traditional separation unit while Column 2 is considered to perform the energy intensive task of the separation processes. Subsequently, the flash unit is employed for the entrainer (IL) regeneration. The simulation of this hybrid distillation process is performed in Aspen Plus (V8.6), where distillation columns (Column 1, Column 2) are modelled by the RadFrac block and flash unit is modelled by the flash evaporation. As compared, conventional process simulation is also performed for the same separation task.

In the design step of process simulation, key operating variables like the number of stages, feed location in Column 2 and the corresponding flow rates of IL are optimized by trade-off and sensitivity analysis. As demonstrated, sensitivity analysis on feed location in Column 2 with certain number of stages $(\mathrm{N}=12)$ for the use of $\left[\mathrm{C}_{3} \mathrm{mPy}\right]^{+}\left[\mathrm{BF}_{4}\right]^{-}$as entrainer at different flow rates is shown in Figure 7. Based on the trade-off analysis, the columns with optimal feed location at different IL flow rates, the 
number of stages and flow rate yielding the minimum stages and energy requirements can be achieved (see Figure 8).

3<smiles>CC[n+]1ccccc1</smiles>

(a)<smiles>CC[n+]1cccc(C)c1</smiles>

(b)<smiles>Cn1ccnc1</smiles>

(c)
5

6

7

8

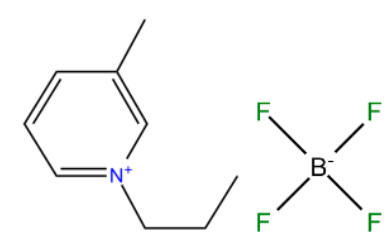

(d)

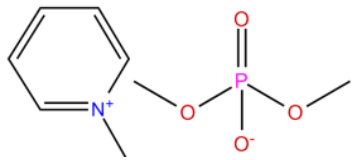

(e)

Figure 6. The structure of the designed ionic liquids for the hybrid distillation process:

(a) $\left[\mathrm{C}_{2} \mathrm{Py}^{+}\left[\mathrm{BF}_{4}\right]^{-}\right.$, (b) $\left[\mathrm{C}_{2} \mathrm{mPy}^{+}\left[\mathrm{BF}_{4}\right]^{-} \text {, (c) }[\mathrm{mIm}]^{+}\left[\mathrm{BF}_{4}\right]^{-} \text {, (d) }\left[\mathrm{C}_{3} \mathrm{mPy}\right]^{+}\left[\mathrm{BF}_{4}\right]^{-} \text {, (e) } \mathrm{C}_{1} \mathrm{Py}\right]^{+}[\mathrm{DMP}]^{-}$

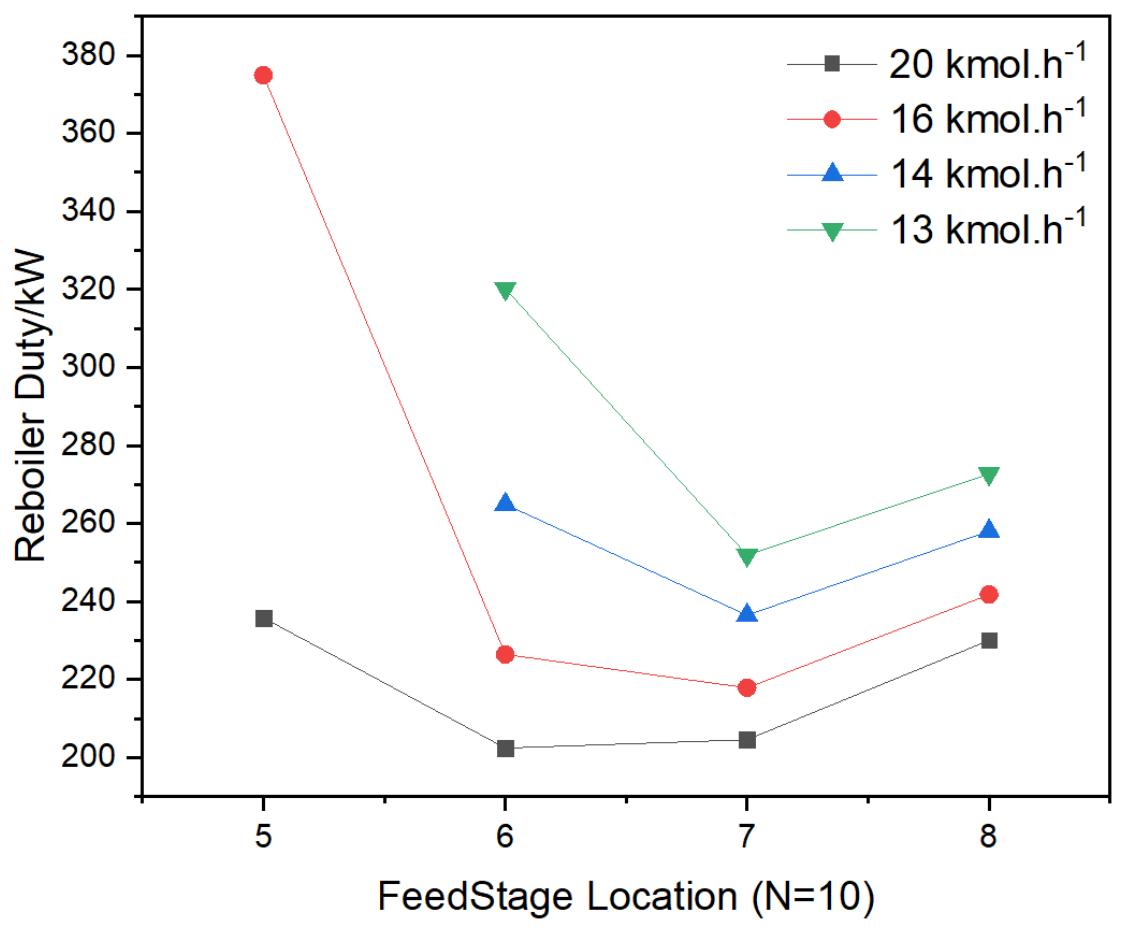

Figure 7: Reboiler heat duty plotted_against feed stage location for meeting the separation task of acetone-water mixture using various amounts of $\left[\mathrm{C}_{3} \mathrm{mPy}\right]^{+}\left[\mathrm{BF}_{4}\right]^{-}$as entrainer.

For the purposes of comparison, the conventional distillation process of both systems is also simulated and optimized. The simulation results of hybrid separation scheme for both systems are summarized in Tables 6 and7. The results indicate that hybrid distillation with all IL identified using different selection criteria have significant energy savings in comparison to the conventional distillation process, where $5987 \mathrm{~kW}$ is required for meeting the methanol purification of $99.8 \mathrm{~mol} \%$ while 7022 $\mathrm{kW}$ is required to obtain the acetone recovery of $97 \mathrm{~mol} \%$ (see Table 6). 


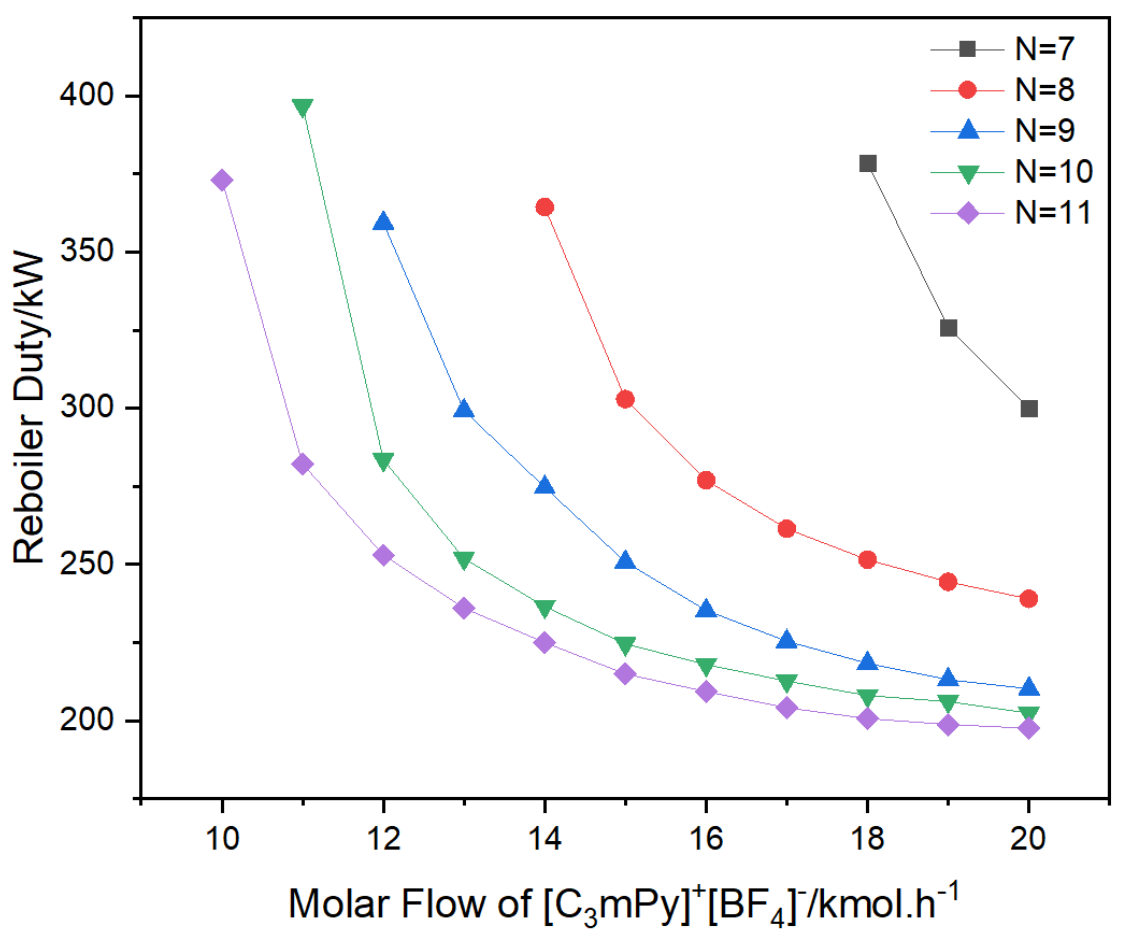

Figure 8: Reboiler heat duty plotted against the molar flow of $\left[\mathrm{C}_{3} \mathrm{mPy}\right]^{+}\left[\mathrm{BF}_{4}\right]^{-}$in the extraction distillation column with different number of column stages $(\mathrm{N})$ for meeting the acetone purification requirement.

5 Table 6: Simulation results for hybrid distillation with IL for methanol-water system

\begin{tabular}{lccc}
\hline Design target & $\alpha_{1,2}^{\infty}$ & $\alpha_{1,2}^{S / F}$ & $\delta_{I L}$ \\
\hline IL & {$\left[\mathrm{C}_{2} \mathrm{Py}\right]^{+}\left[\mathrm{BF}_{4}\right]^{-}$} & {$\left[\mathrm{C}_{2} \mathrm{mPy}\right]^{+}\left[\mathrm{BF}_{4}\right]^{-}$} & {$\left[\mathrm{mIm}^{+}\left[\mathrm{BF}_{4}\right]^{-}\right.$} \\
Entrainer flow rate, kmol/h & 11 & 8 & 12 \\
Column 1 & & & \\
$\quad$ Number of stages & 16 & 16 & 16 \\
Feed stage & 11 & 11 & 11 \\
$\quad$ Reflux ratio & 1.43 & 1.43 & 1.43 \\
Reboiler heat duty, kW & 4991 & 4991 & 4991 \\
Column 2 & 6 & & 5 \\
Number of stages & 2 & 6 & 2 \\
$\quad$ Entrainer stage & 4 & 2 & 4 \\
Feed stage & 0.119 & 4 & 0.091 \\
Reflux ratio & 186 & 0.095 & 124 \\
$\quad$ Reboiler heat duty, kW & & 141 & 0.1 \\
Flash drum & 0.1 & & 76 \\
$\quad$ Operating pressure (bar) & 67 & 0.1 & 5191 \\
$\quad$ Heat duty, kW & 5244 & 5197 & \\
Overall heat duty, kW & &
\end{tabular}

6 For methanol-water system, all three IL candidates have similar energy requirement. Among them, $7 \quad[\mathrm{mIm}]^{+}\left[\mathrm{BF}_{4}\right]^{-}$requires the least column stages and $\left[\mathrm{C}_{2} \mathrm{mPy}\right]^{+}\left[\mathrm{BF}_{4}\right]^{-}$is found to be the best selection in 8 terms of the solvent consumption. For the separation of acetone-water mixture, all three selected ILs 9 provide significant energy savings. Although $[\mathrm{mIm}]^{+}\left[\mathrm{BF}_{4}\right]^{-}$requires the least number of column stages 10 while, $\left[\mathrm{C}_{2} \mathrm{mPy}\right]^{+}\left[\mathrm{BF}_{4}\right]^{-}$shows the most attractive separation performance with lowest energy input 
1 and solvent consumption. Calculation results of both cases highlight the reliability and applicability 2 of using $\alpha_{1,2}^{S / F}$ as design target to screen suitable ILs in the CAILD problem for separation processes 3 of aqueous solution.

4 Although, only one main column is required for the conventional distillation process, hybrid scheme 5 with IL can significantly reduce the energy consumption, especially for the acetone-water system 6 where the purification would be very difficult after 96 mol\% acetone. Additionally, the overall flow 7 rate of ILs in the hybrid process is less than $20 \mathrm{kmol} / \mathrm{h}$, which provides possibility of addressing the 8 operational and economic constraints (e.g. high viscosity, high cost) in the use of ILs as solvents.

9 Table 7: Simulation results for hybrid distillation with IL for acetone-water system

\begin{tabular}{lccc}
\hline Design target & $\alpha_{1,2}^{\infty}$ & $\alpha_{1,2}^{S / F}$ & $\delta_{I L}$ \\
\hline IL & {$\left[\mathrm{C}_{1} \mathrm{Py}\right]^{+}[\mathrm{DMP}]^{-}$} & {$\left[\mathrm{C}_{3} \mathrm{mPy}\right]^{+}\left[\mathrm{BF}_{4}\right]^{-}$} & {$[\mathrm{mIm}]^{+}\left[\mathrm{BF}_{4}\right]^{-}$} \\
Entrainer flow rate, kmol/h & 17 & 14 & 16 \\
Column 1 & & & 15 \\
$\quad$ Number of stages & 15 & 15 & 12 \\
Feed stage & 12 & 12 & 0.395 \\
Reflux ratio & 0.395 & 0.395 & 3097 \\
Reboiler heat duty, kW & 3097 & 3097 & \\
Column 2 & & & 2 \\
Number of stages & 12 & 10 & 7 \\
Entrainer stage & 2 & 2 & 0.289 \\
Feed stage & 8 & 7 & 230 \\
Reflux ratio & 0.275 & 0.275 & \\
Reboiler heat duty, $\mathrm{kW}$ & 241 & 233 & 0.1 \\
Flash drum & & & 293 \\
$\quad$ Operating pressure (bar) & 0.1 & 0.1 & 3620 \\
Heat duty, kW & 286 & 278 & \\
Overall heat duty, kW & 3624 & 3608 & \\
\hline
\end{tabular}

\subsection{Bio-oxidation of alcohols}

Aldehydes are important intermediates used in the manufacture of solvents, resins, plasticizers and pharmaceuticals because of their high chemical activity (https://www.britannica.com/science/aldehyde). Some sugars, hormones or vitamin derivatives are aldehydes (Smith and March, 2006). There are several methods for synthesizing aldehydes, and the method of alcohols dehydrogenation is widely used in industries (Colquhoun et al., 1991). In this work, we select the oxidation of alcohols as the synthesis method to produce aldehydes and the biocatalyst (galactose oxidase) is used in these bio-reactions (see Table 8). Galactose oxidase is a copperdependent enzyme that has shown promising results for the bio-catalysis of the oxidation of primary alcohols to the corresponding aldehydes (Whittaker, 2003). Although this synthesis method has many advantages such as low environmental impact and high reaction specification, the limitations of enzymes associated with product and substrate inhibition result in highly diluted product, which leads to difficulties in downstream separations. For this reason, the proposed hybrid reaction-separation scheme (see Figure 3) is considered as the solution for such limitations, and the application is illustrated through the bio-oxidation of benzyl alcohol to produce benzaldehyde.

Experimental work regarding the bio-catalytic oxidation of primary alcohols to aldehydes has been carried out by Toftgaard Pedersen et al. (2015). In their work, the oxidation of benzyl alcohol to 
1 benzaldehyde using enzyme Galactose oxidase was in focus and a reaction kinetic model, as expressed

2 by Eq.39, was developed.

$$
\frac{d C_{S}}{d t}=-r=-\frac{k_{c a t} C_{E} C_{S} C_{O}}{C_{S} C_{O}+K_{M O} C_{S}+K_{M S} C_{O}\left(1+\frac{C_{P}}{K_{I P}}\right)}
$$

Table 8: Information of the studied bio-oxidation of alcohols

\begin{tabular}{ll}
\hline Reaction scheme & $\mathrm{A}+\mathrm{B} \longrightarrow \mathrm{C}+\mathrm{D}$ \\
Reaction class & Oxidation \\
Reactants & Primary alcohol, oxygen \\
Products & Aldehyde, water \\
Catalyst & Galactose oxidase \\
Reaction class form & \\
&
\end{tabular}

where $r$ is the reaction rate $(\mathrm{mmol} / 1 \cdot \mathrm{min})$ and $k_{\text {cat }}$ is the rate constant $(\mu \mu \mathrm{mol} / \mathrm{min} \cdot \mathrm{mg} \mathrm{CFE}($ cell-free extract)). $C_{O}, C_{S}, C_{P}$ are the concentrations of oxygen, substrate and product, respectively (mmol/l); $C_{E}$ is the enzyme concentration in $\mathrm{mg} / \mathrm{l} ; K_{M O}, K_{M S}, K_{I P}$ are Michaelis constants for oxygen, benzyl alcohol and benzaldehyde, respectively $(\mathrm{mmol} / \mathrm{l})$. Table 9 summarizes the reactor conditions and the kinetic parameters for this bio-reaction process.

Table 9: Reactor conditions and kinetic parameters for alcohols dehydrogenation using galactose oxidase as biocatalysts

\begin{tabular}{llcl}
\hline & \multicolumn{3}{c}{ Kinetic parameters } \\
\hline Parameters & value & Parameters & value \\
$\mathrm{k}_{\text {cat }}(\mathrm{kmol} / \mathrm{kg} \mathrm{CFE})$ & 0.066 & $\mathrm{C}_{\mathrm{E}}\left(\mathrm{kg} / \mathrm{m}^{3}\right)$ & 0.0011 \\
$\mathrm{~K}_{\mathrm{MS}}\left(\mathrm{kmol} / \mathrm{m}^{3}\right)$ & 0.051 & $\mathrm{C}_{\mathrm{O}}\left(\mathrm{kg} / \mathrm{m}^{3}\right)$ & 0.5 \\
$\mathrm{~K}_{\mathrm{IP}}\left(\mathrm{kmol} / \mathrm{m}^{3}\right)$ & 0.0017 & $\mathrm{C}_{\mathrm{S}}\left(\mathrm{kg} / \mathrm{m}^{3}\right)$ & 0.265 \\
\hline & & Reactor conditions & \\
\hline $\mathrm{T}\left({ }^{\circ} \mathrm{C}\right)$ & 25 & $\mathrm{C}_{\text {alcohol }}\left(\mathrm{kmol} / \mathrm{m}^{3}\right)$ & 0.05 \\
$\mathrm{P}(\mathrm{atm})$ & 1 & Aeration $\left(\mathrm{vvm}{ }^{*}\right)$ & 0.5 \\
\hline
\end{tabular}

${ }^{*}$ vvm - volume of air (l) passing through a volume of medium (l) per unit time (min).

The performance of a reaction can be evaluated by the yield $(Y)$, which is generally described as

$$
\mathrm{Y}=\frac{n_{p}-n_{0, p}}{n_{0, r}}
$$

where, $n_{0, p}$ and $n_{p}$ are the initial moles of product and the moles of product formed, respectively, while $n_{0, r}$ is the moles of the limiting reactant (Liese et al., 2006).

Based on the developed dynamic model (Eqs.26-38), the molar composition in the reactor with respect to time is calculated using the reaction conditions and the kinetic parameters presented in Table 9. For comparison purposes, the simulation of the batch operation is also performed. Figure 9 illustrates the product yield and reaction rate between batch operation and continuous product removal (hybrid 
reaction-separation scheme). Clearly the hybrid scheme involving continuous product removal has a better reaction and yield performance than the batch operation.
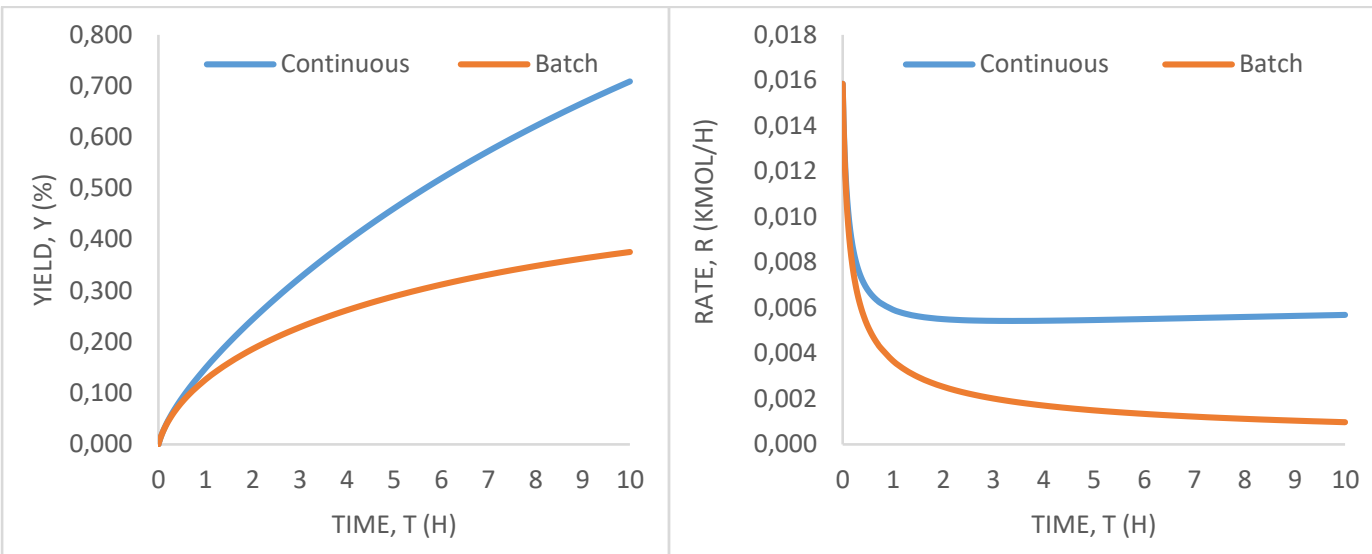

4 Figure 9: Comparison between batch operation and continuous product removal

In the downstream separation process, the solvent should be able to extract the product(s) from the aqueous phase and the reactant(s), and it should also be easily separated from the product(s). Since the separation technique of liquid-liquid extraction is considered, the separation feasibility of the selected solvent can be evaluated by the ternary plot for system of water + aldehyde + solvent.

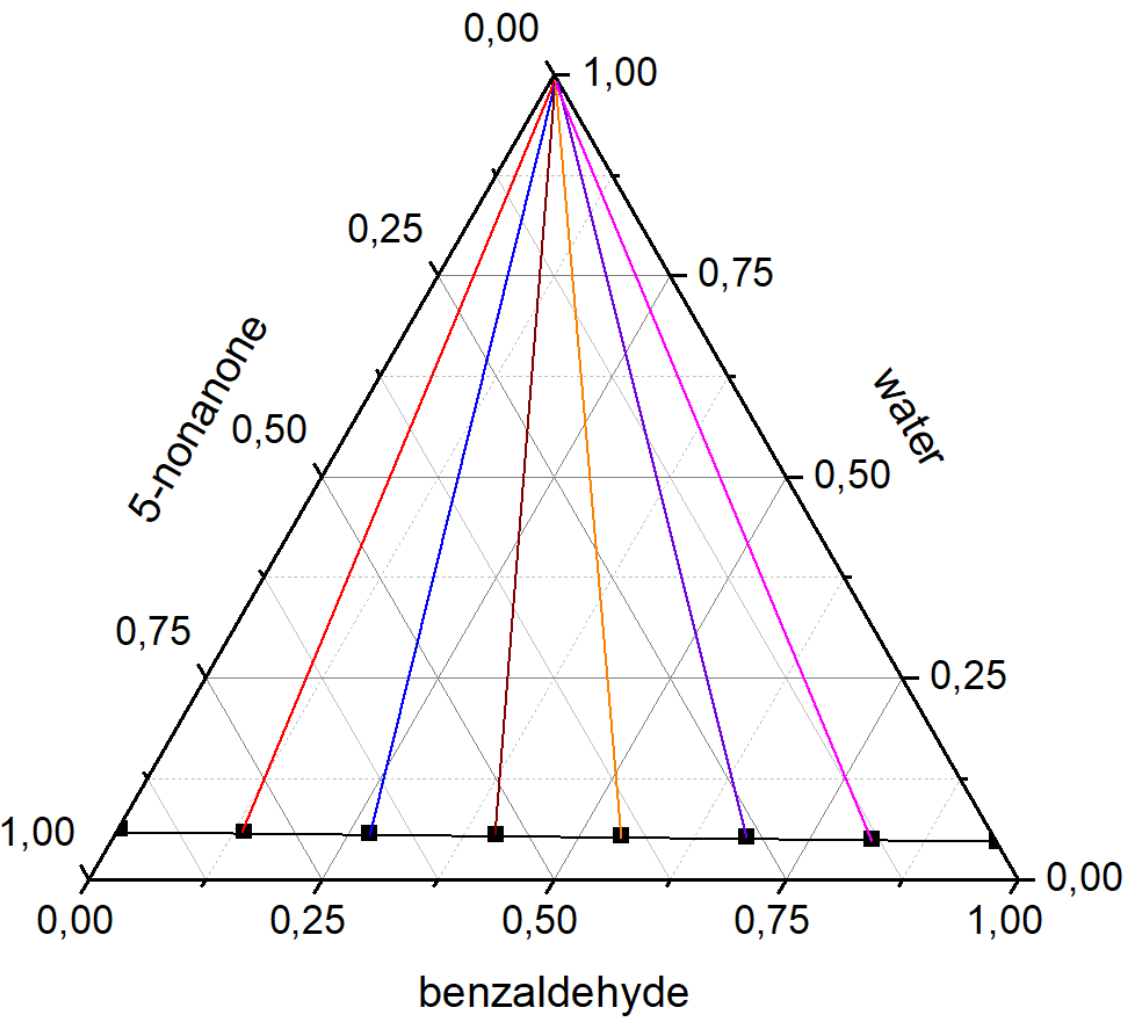

Figure 10. Ternary plot for system of water + benzaldehyde +5 -nonanone

For bio-oxidation process of benzyl alcohol, an organic solvent, 5-nonanone (Figure 11(a)), is generated to separate benzaldehyde from water by using Pro-CAMD in ICAS (Gani et al., 1997) as organic solvent screening tool. Figure 10 presents the ternary plot for system of water + benzaldehyde +5 -nonanone. Although 5-nonanone is able to separate benzaldehyde from water, it is difficult to 
separate benzaldehyde from benzyl alcohol + water due to the similarities between benzaldehyde and benzyl alcohol. Moreover, the recovery of benzaldehyde from n-octane is also difficult. On the other hand, experimental data in some published works (Heintz et al., 2006) shows that ILs might be the potential solvents to this separation task.

In this case, well-studied groups containing 2 cations, 2 anions and 2 substituents (see Table 10) were considered as molecular building blocks in CAILD. Table 11 summaries the design information of the MINLP-based CAILD problem for this case study. The formulated MINLP problem is solved in the modelling system GAMS 24.4.6 on an Intel(R) Xeon(R) E5-1620 3.70 GHz PC running Windows 10 system, here we use a deterministic global optimization solver, LINDOGLOBAL.

10 Table 10: Molecular building blocks for IL design in the bio-oxidation of benzyl alcohol

\begin{tabular}{|c|c|c|c|c|c|}
\hline Type & Group & Subgroup & Type & Group & Subgroup \\
\hline \multirow[t]{6}{*}{ Cations } & {$[\mathrm{Im}]^{+}$} & {$[\mathrm{Im}]^{+}$} & Anions & {$\left[\mathrm{Tf}_{2} \mathrm{~N}\right]^{-}$} & {$\left[\mathrm{Tf}_{2} \mathrm{~N}\right]^{-}$} \\
\hline & & {$[\mathrm{mIm}]^{+}$} & & {$\left[\mathrm{BF}_{4}\right]^{-}$} & {$\left[\mathrm{BF}_{4}\right]^{-}$} \\
\hline & {$[\mathrm{N}]^{+}$} & {$\left[\mathrm{CH}_{3} \mathrm{~N}\right]^{+}$} & Substituents & $\mathrm{CH}_{3}$ & $\mathrm{CH}_{3}$ \\
\hline & & {$\left[\mathrm{C}_{2} \mathrm{H}_{5} \mathrm{~N}\right]^{+}$} & & & $\mathrm{CH}_{2}$ \\
\hline & & {$\left[\mathrm{C}_{3} \mathrm{H}_{7} \mathrm{~N}\right]^{+}$} & & & \\
\hline & & {$\left[\mathrm{C}_{4} \mathrm{H}_{9} \mathrm{~N}\right]^{+}$} & & & \\
\hline
\end{tabular}

Table 11: Design information of MINLP-based CAILD problem for the bio-oxidation of alcohols

\begin{tabular}{|c|c|c|c|c|c|c|}
\hline \multirow{2}{*}{$\begin{array}{l}\text { Number of } \\
\text { continuous } \\
\text { variables }\end{array}$} & \multirow{2}{*}{$\begin{array}{l}\text { Number } \\
\text { binary } \\
\text { variables }\end{array}$} & \multirow{2}{*}{$\begin{array}{l}\text { Number } \\
\text { integer } \\
\text { variables }\end{array}$} & \multirow[t]{2}{*}{ of } & \multicolumn{3}{|c|}{ Number of constraints } \\
\hline & & & & $\begin{array}{l}\text { IL } \\
\text { structure }\end{array}$ & $\begin{array}{l}\text { Thermodynamic } \\
\text { properties }\end{array}$ & $\begin{array}{l}\text { Physical } \\
\text { properties }\end{array}$ \\
\hline 688 & 26 & 156 & & 88 & 543 & 4 \\
\hline
\end{tabular}

The same IL $\left[\mathrm{C}_{4} \mathrm{mIm}\right]^{+}\left[\mathrm{Tf}_{2} \mathrm{~N}\right]^{-}$is identified from the solution of the MINLP-based CAILD problem using different design targets (i.e. $S$ and $\{D \times S\}$ ). Table 12 provides the model statics from GAMS solution for this MINLP problem. The structure of $\left[\mathrm{C}_{4} \mathrm{mIm}\right]^{+}\left[\mathrm{Tf}_{2} \mathrm{~N}\right]^{-}$is given by Figure $11(\mathrm{~b})$ and the UNIFAC-IL calculated LLE for system of water + benzaldehyde $+\left[\mathrm{C}_{4} \mathrm{mIm}\right]^{+}\left[\mathrm{Tf}_{2} \mathrm{~N}\right]^{-}$is presented in Figure 12. This results can also be partly verified by the experimental work from Heintz et al. (2006), where the activity coefficients at infinite diution of of linear and branched C1-C6 alcohols and aldehydes in $\left[\mathrm{C}_{6} \mathrm{mIm}\right]^{+}\left[\mathrm{Tf}_{2} \mathrm{~N}\right]^{-}$shows its possibility to separate aldehydes from alcohols.

Table 12: Model statistics from GAMS solution for the bio-oxidation of alcohols

\begin{tabular}{|c|c|c|c|c|c|c|c|}
\hline $\begin{array}{l}\text { Number of } \\
\text { continuous } \\
\text { variables }\end{array}$ & $\begin{array}{l}\text { Number } \\
\text { of binary } \\
\text { variables }\end{array}$ & $\begin{array}{l}\text { Number } \\
\text { of } \\
\text { equations }\end{array}$ & $\begin{array}{l}\text { Number } \\
\text { of } \\
\text { constraints }\end{array}$ & $\begin{array}{l}\text { Objective } \\
\text { function }\end{array}$ & $\begin{array}{l}\text { Number } \\
\text { iterations }\end{array}$ & of & CPU time (s) \\
\hline \multirow{2}{*}{688} & \multirow{2}{*}{26} & \multirow{2}{*}{636} & \multirow{2}{*}{635} & $S$ & 3000621 & & 458 \\
\hline & & & & $\{D \times S\}$ & 1854845 & & 266 \\
\hline
\end{tabular}

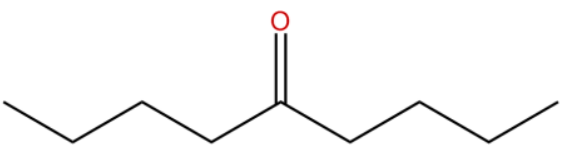

(a)

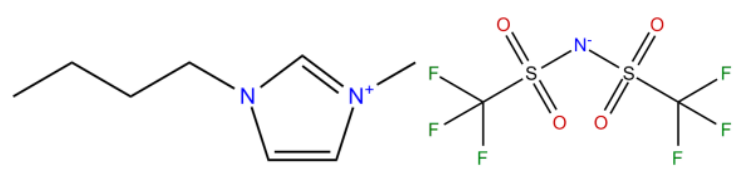

(b)

Figure 11. The structures of the selected organic and IL solvents: (a) 5-nonanone, (b) $\left[\mathrm{C}_{4} \mathrm{mIm}\right]^{+}\left[\mathrm{Tf}_{2} \mathrm{~N}\right]^{-}$ 


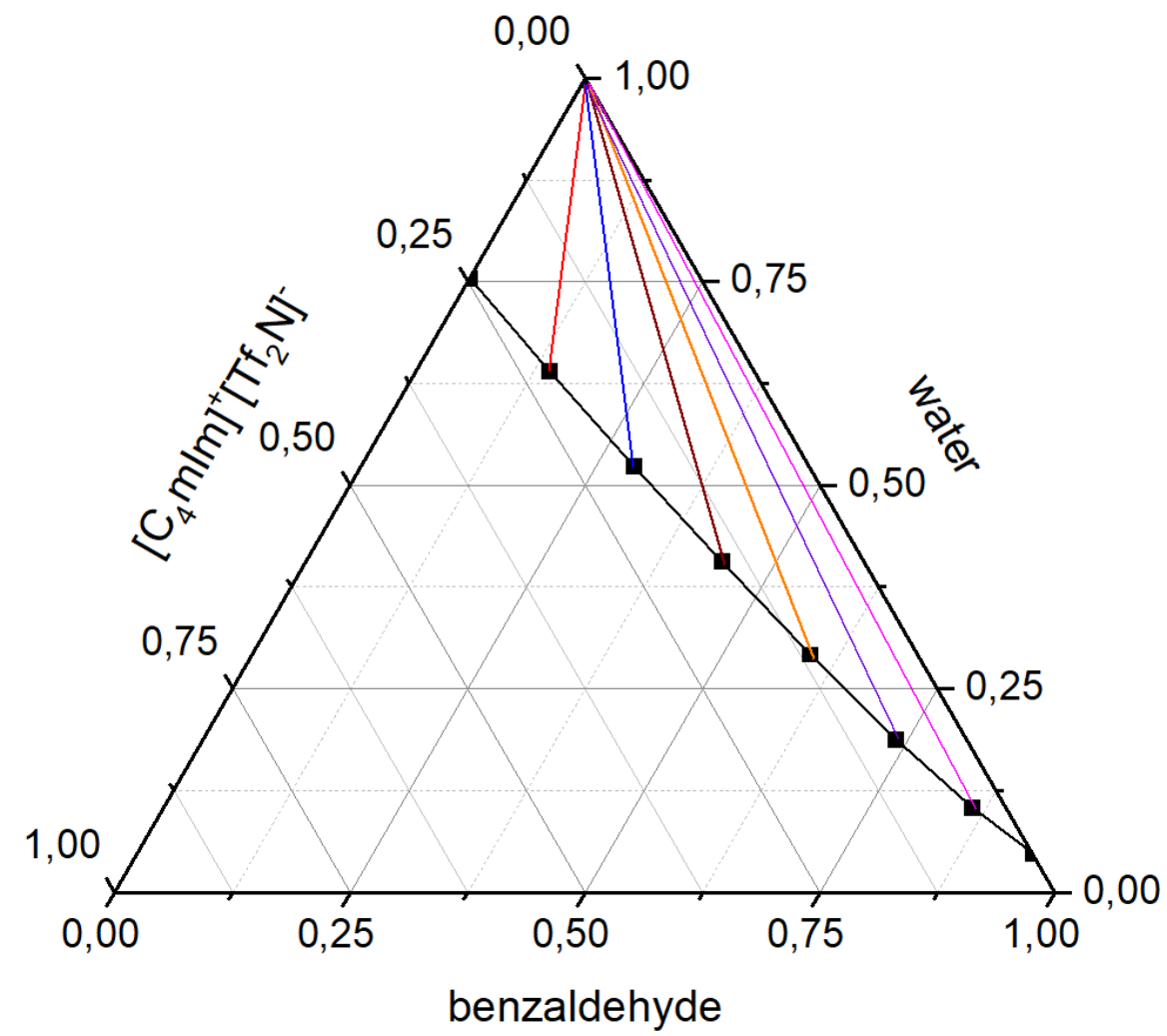

Figure 12. Ternary plot for system of water + benzaldehyde $+\left[\mathrm{C}_{4} \mathrm{mIm}\right]^{+}\left[\mathrm{Tf}_{2} \mathrm{~N}\right]^{-}$

\section{Conclusions}

This work presents a design method for hybrid process schemes that have the potential to satisfy the demands of lower energy consumption and reduced waste, as well as satisfying product specifications. The proposed IL-based hybrid schemes complement the ones using membranes (e.g. Figure 2a). Although both ILs and membranes have their regions of efficient operation, their potential for process improvements greatly depends on the studied system. In some cases, hybrid schemes involving ILs have guaranteed energy savings, but the ones using membranes have not, and vice versa. For some systems, if both ILs and membranes are available, the best scheme could be selected on the basis of an agreed set of performance criteria. For the purposes of process simulation, parameters of submodels used to calculate four temperature-dependent properties of ILs were regressed based on a wide range of collected experimental data. By using this design method, optimal ILs are designed and further evaluated for case studies involving separation of aqueous solutions and bio-oxidation of alcohols. The identified ILs in both cases lead to process performance improvements and among the well-studied anions, $\left[\mathrm{BF}_{4}\right]^{-}$was found the most attractive for the extractive distillation of aqueous solutions.

In our present work, the design problem of hybrid process was addressed by a two-stage based solution strategy, although more reliable global optimization results consist of optimal IL solvent and corresponding process specifications can be simultaneous obtained by using an integrated solvent and process design method, computational efficiency remains a limiting factor with a significant increase in the complexity and the design space of the global-based MINLP problem. Since the limited property information of IL containing systems, only well-studied IL groups were considered as building blocks. However, more attractive IL candidates may be generated once further IL groups are included where their property information is available. Additionally, verification by experiment will be necessary considering some designed IL(s) have never been studied or synthesized before. Future 
work will expand the specific design method into a generalized one that covers a wide range of processes with "hot-spots", and improve the CAILD toolbox consisting of databases, models, and solution strategies for hybrid schemes.

\section{Acknowledgements}

This research work was supported by the China Scholarship Council (No. 201708440264) and the

6 Technical University of Denmark. The authors would like to thank PhD student Nipun Garg from the

7 Technical University of Denmark for many useful discussions.

\section{$8 \quad$ Appendix. Property predction modeling}

9 In Eq. 14, the impact of parameters $C_{4 p L}$ and $C_{5 p L}$ on the heat capacity of ILs is negligible and therefore 10 their values are set to zero. Other modeling parameters $C_{m p L}(m=1,2,3)$ can be obtained from group 11 contributions, as shown in Eq.A1.

$$
C_{m p L}=\sum_{i=1}^{k} n_{i} c_{i, m p L}
$$

where $k$ represents the total number of different groups in the IL molecule and $n_{i}$ denotes the number of groups of type $i$. Group contribution $c_{i, m \eta}(m=1,2,3)$ are regressed by fitting experimental data into Eq.14 to minimize the $A A R D(\%)$, as expressed by Eq.A2.

16 Table A1: Regressed Group Contribution Parameters $c_{i, m p L}(m=1,2,3)$ for Eq.A1 in the

17 Temperature Range of $189.66-524.87 \mathrm{~K}$

\begin{tabular}{|c|c|c|c|}
\hline & $c_{i, 1 p L}\left(\mathrm{~J} \cdot \mathrm{mol}^{-1} \cdot \mathrm{K}^{-1}\right)$ & $c_{i, 2 p L}\left(\mathrm{~J} \cdot \mathrm{mol}^{-1} \cdot \mathrm{K}^{-2}\right)$ & $c_{i, 3 p L}\left(\mathrm{~J} \cdot \mathrm{mol}^{-1} \cdot \mathrm{K}^{-3}\right)$ \\
\hline \multicolumn{4}{|l|}{ Substituents } \\
\hline $\mathrm{CH}_{3}$ & 1095.40 & -7.998 & 0.014 \\
\hline $\mathrm{CH}_{2}$ & 43.48 & -0.106 & 2.31E-04 \\
\hline $\mathrm{dmN}$ & 178.245 & -0.864 & 0.002 \\
\hline \multicolumn{4}{|l|}{ Cations } \\
\hline 1,3-dmIm (+) & 12.35 & -1.784 & 4.12E-05 \\
\hline 1-mPy (+) & -104.238 & -0.739 & -0.002 \\
\hline 1,1-dmPyr (+) & 0.00 & -1.713 & $1.08 \mathrm{E}-04$ \\
\hline $\operatorname{Am}(1) 111(+)$ & 728.417 & -5.938 & 0.006 \\
\hline $\mathrm{TDPh}(+)$ & -1641.998 & 13.508 & -0.0230 \\
\hline 1,1-dmPip (+) & 37.277 & -1.632 & 0.00 \\
\hline \multicolumn{4}{|l|}{ Anions } \\
\hline$\left[\mathrm{Tf}_{2} \mathrm{~N}\right]^{-}$ & 278.805 & 2.542 & $-5.09 \mathrm{E}-04$ \\
\hline$\left[\mathrm{BF}_{4}\right]^{-}$ & 175.466 & 1.984 & $2.04 \mathrm{E}-04$ \\
\hline$\left[\mathrm{PF}_{6}\right]^{-}$ & 15.59 & 3.145 & -0.001 \\
\hline$[\mathrm{Cl}]^{-}$ & 196.372 & 1.519 & $9.47 \mathrm{E}-04$ \\
\hline$[\mathrm{Ac}]^{-}$ & 244.629 & 1.505 & 0.001 \\
\hline$\left[\mathrm{MeSO}_{4}\right]^{-}$ & -274.08 & 4.791 & -0.004 \\
\hline$\left[\mathrm{EtSO}_{4}\right]^{-}$ & 315.9 & 1.566 & 9.44E-04 \\
\hline$\left[\mathrm{CF}_{3} \mathrm{SO}_{3}\right]^{-}$ & 75.285 & 3.134 & -0.002 \\
\hline$[\mathrm{Br}]^{-}$ & 170.98 & 1.745 & $4.16 \mathrm{E}-04$ \\
\hline$\left[\mathrm{CF}_{3} \mathrm{COO}\right]^{-}$ & 196.953 & 2.102 & $2.26 \mathrm{E}-05$ \\
\hline$\left[\mathrm{N}(\mathrm{CN})_{2}\right]^{-}$ & 226.563 & 1.743 & $5.45 \mathrm{E}-04$ \\
\hline$\left[\mathrm{C}(\mathrm{CN})_{3}\right]^{-}$ & 541.00 & 0.00 & 0.003 \\
\hline$[\mathrm{DMP}]^{-}$ & -3520.00 & 24.842 & -0.035 \\
\hline$\left[\mathrm{FeCl}_{4}\right]^{-}$ & 36.00 & 3.39 & -0.002 \\
\hline
\end{tabular}




\begin{tabular}{lrrr}
\hline$\left[\mathrm{SCN}^{-}\right.$ & & & \\
{$\left[\mathrm{eFAP}^{-}\right]^{-}$} & -398.00 & 4.956 & -0.003 \\
& 2192.205 & -9.673 & 0.02 \\
\hline
\end{tabular}

1

$$
O . F .=A A R D(\%)=\frac{100 \times \sum_{i=1}^{N}\left|\left(\rho_{c a l}-\rho_{\text {exp }}\right) / \rho_{\text {exp }}\right|_{i}}{N}
$$

$$
R D(\%)=100 \times\left(\rho_{\text {cal }}-\rho_{\text {exp }}\right) / \rho_{\text {exp }}
$$

In Eqs.A2 and A3, $N$ represents the number of experimental data points while subscripts exp and cal denote experimental and calculated properties, respectively.

A number of 2022 data points for 67 ILs covering 6 cation cores, 16 anions and 3 substituents in a wide range of temperature, $189.66-524.87 \mathrm{~K}$ are used. The AARD $(\%)$ of this estimation model for heat capacity is $0.7 \%$. The obtained group contributions $c_{i, m p L}$ are provided in Table A1 and comparison between experimental and calculated heat capacity using this model are given in Figure A1.

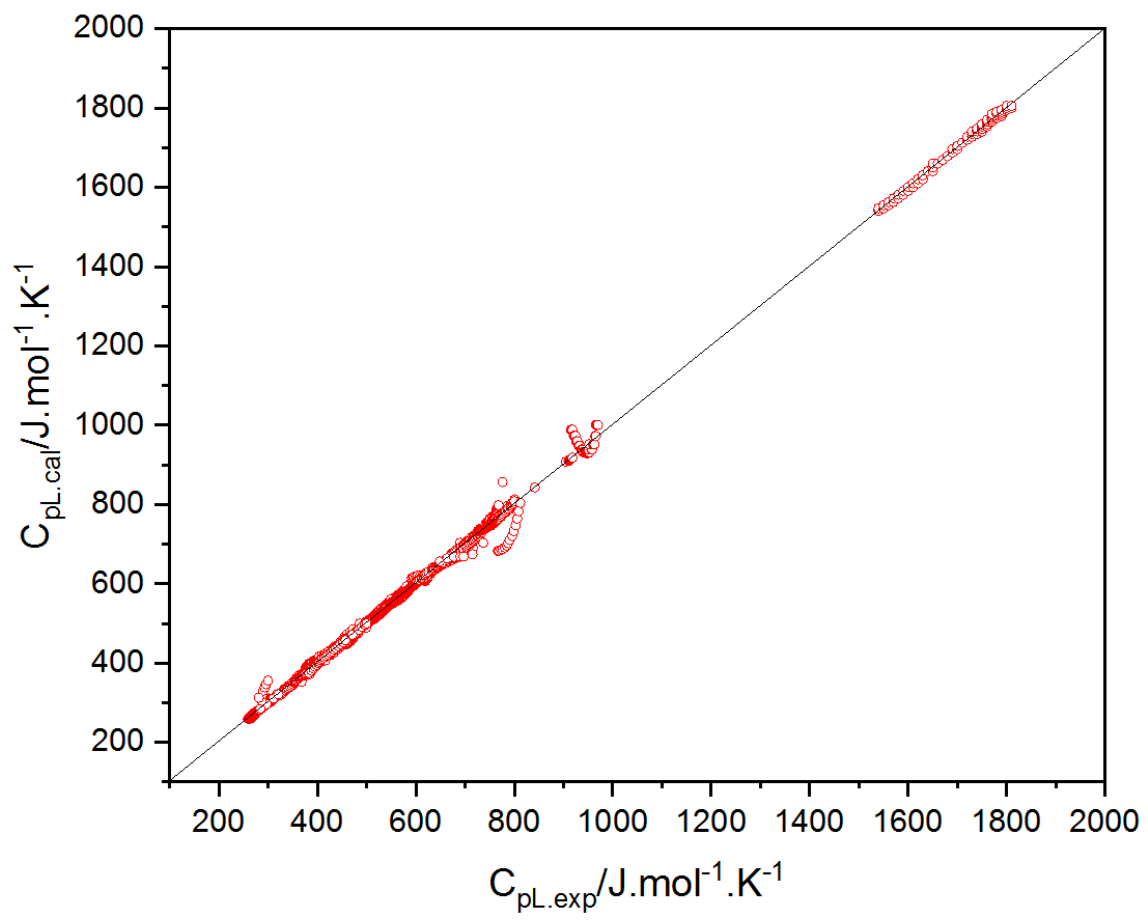

Figure A1. Comparison between experimental and calculated heat capacity using estimation model, Eq.14

For the surface tension of ILs, the values of parameters $C_{m \sigma}(m=4,5, \cdots, 10)$ in Eq.15 are given as zero because of their negligible influence. Remaining parameters $C_{m \sigma}(m=1,2,3)$ can be calculated according to

$$
C_{m \sigma}=\sum_{i=1}^{k} n_{i} c_{i, m \sigma}
$$

where $k$ is the total number of different groups in the molecule while $n_{i}$ denotes the number of groups of type $i$, and group contributions $c_{i, m \sigma}(m=1,2,3)$ are obtained by the regression of experimental data into Eq.15 using Eq.A5 as the objective function. 


$$
O . F .=\frac{100 \times \sum_{i=1}^{N}\left|\left(\sigma_{c a l}-\sigma_{e x p}\right) / \sigma_{e x p}\right|_{i}}{N}
$$

2 A number of 1577 data points for $110 \mathrm{ILs}$ involving 6 cation cores, 20 anions and 2 substituents in 3 the temperature range of 262.89-393 $\mathrm{K}$ are employed. The AARD (\%) of this estimation model for 4 surface tension is $3.4 \%$. The regressed group contribution parameters $c_{i, m} \sigma$ are provided in Table A2 5 and comparison between experimental and calculated surface tension using this model is given in 6 Figure A2.

7 Table A2: Regressed Group Contribution Parameters $c_{i, m \sigma}(m=1,2,3)$ for Eq.A4 in the 8 Temperature Range of 262.89-393 K

\begin{tabular}{|c|c|c|c|}
\hline & $c_{i, 1 \sigma}\left(\mathrm{N} \cdot \mathrm{m}^{-1}\right)$ & $c_{i, 2 \sigma}\left(\mathrm{N} \cdot \mathrm{m}^{-1} \cdot \mathrm{K}^{-1}\right)$ & $c_{i, 3 \sigma}\left(\mathrm{N} \cdot \mathrm{m}^{-1} \cdot \mathrm{K}^{-2}\right)$ \\
\hline \multicolumn{4}{|l|}{ Substituents } \\
\hline $\mathrm{CH}_{3}$ & $8.48 \mathrm{E}-04$ & $2.18 \mathrm{E}-04$ & $-2.07 \mathrm{E}-07$ \\
\hline $\mathrm{CH}_{2}$ & 0.005 & $-4.23 \mathrm{E}-05$ & $6.90 \mathrm{E}-08$ \\
\hline \multicolumn{4}{|l|}{ Cations } \\
\hline 1,3-dmIm (+) & 0.003 & $2.41 \mathrm{E}-04$ & $-2.31 \mathrm{E}-07$ \\
\hline $1-\mathrm{mPy}(+)$ & $-4.43 \mathrm{E}-04$ & $2.71 \mathrm{E}-04$ & $-2.78 \mathrm{E}-07$ \\
\hline 1,1-dmPyr (+) & $-2.10 \mathrm{E}-05$ & $2.46 \mathrm{E}-04$ & $-1.95 \mathrm{E}-07$ \\
\hline $\operatorname{Am}(1) 111(+)$ & $-4.90 \mathrm{E}-04$ & $3.40 \mathrm{E}-04$ & $-4.34 \mathrm{E}-07$ \\
\hline $\mathrm{TDPh}(+)$ & $-6.00 \mathrm{E}-04$ & $1.89 \mathrm{E}-04$ & $-1.82 \mathrm{E}-07$ \\
\hline 1,1-dmPip (+) & $-7.47 \mathrm{E}-05$ & 2.71E-04 & $-2.85 \mathrm{E}-07$ \\
\hline \multicolumn{4}{|l|}{ Anions } \\
\hline$\left[\mathrm{Tf}_{2} \mathrm{~N}\right]^{-}$ & $-3.29 \mathrm{E}-04$ & $1.89 \mathrm{E}-05$ & $-2.56 \mathrm{E}-07$ \\
\hline$\left[\mathrm{BF}_{4}\right]^{-}$ & $-4.71 \mathrm{E}-04$ & $1.30 \mathrm{E}-04$ & $-4.90 \mathrm{E}-07$ \\
\hline$\left[\mathrm{PF}_{6}\right]^{-}$ & $3.11 \mathrm{E}-04$ & $5.56 \mathrm{E}-05$ & $-2.90 \mathrm{E}-07$ \\
\hline$[\mathrm{Cl}]^{-}$ & 8.60E-04 & $7.82 \mathrm{E}-05$ & $-3.46 \mathrm{E}-07$ \\
\hline$[\mathrm{Ac}]^{-}$ & $3.30 \mathrm{E}-06$ & $6.54 \mathrm{E}-05$ & $-3.87 \mathrm{E}-07$ \\
\hline$\left[\mathrm{MeSO}_{4}\right]$ & $-1.75 \mathrm{E}-04$ & $1.62 \mathrm{E}-04$ & $-5.96 \mathrm{E}-07$ \\
\hline$\left[\mathrm{EtSO}_{4}\right]^{-}$ & $5.50 \mathrm{E}-05$ & $1.21 \mathrm{E}-04$ & $-4.90 \mathrm{E}-07$ \\
\hline$\left[\mathrm{CF}_{3} \mathrm{SO}_{3}\right]^{-}$ & $4.86 \mathrm{E}-04$ & $2.33 \mathrm{E}-05$ & $-2.56 \mathrm{E}-07$ \\
\hline$[\mathrm{Br}]^{-}$ & $-7.32 \mathrm{E}-05$ & $8.57 \mathrm{E}-05$ & $-3.89 \mathrm{E}-07$ \\
\hline$\left[\mathrm{CF}_{3} \mathrm{COO}\right]^{-}$ & $-2.39 \mathrm{E}-04$ & $3.79 \mathrm{E}-05$ & $-3.09 \mathrm{E}-07$ \\
\hline$\left[\mathrm{N}(\mathrm{CN})_{2}\right]^{-}$ & $-3.10 \mathrm{E}-04$ & $1.16 \mathrm{E}-04$ & $-3.91 \mathrm{E}-07$ \\
\hline$\left[\mathrm{C}(\mathrm{CN})_{3}\right]^{-}$ & 0.001 & $1.36 \mathrm{E}-04$ & $-4.97 \mathrm{E}-07$ \\
\hline$\left[\mathrm{AlCl}_{4}\right]^{-}$ & $-3.51 \mathrm{E}-04$ & $1.04 \mathrm{E}-04$ & $-4.17 \mathrm{E}-07$ \\
\hline$\left[\mathrm{InCl}_{4}\right]^{-}$ & $-2.93 \mathrm{E}-05$ & 8.71E-05 & $-3.61 \mathrm{E}-07$ \\
\hline$[\mathrm{DMP}]^{-}$ & $-5.56 \mathrm{E}-05$ & $1.70 \mathrm{E}-04$ & $-6.51 \mathrm{E}-07$ \\
\hline$\left[\mathrm{FeCl}_{4}\right]^{-}$ & $-1.09 \mathrm{E}-04$ & $9.11 \mathrm{E}-05$ & $-3.95 \mathrm{E}-07$ \\
\hline$\left[\mathrm{GaCl}_{2}\right]^{-}$ & $-2.28 \mathrm{E}-05$ & $1.07 \mathrm{E}-04$ & $-4.24 \mathrm{E}-07$ \\
\hline$\left[\mathrm{Pf}_{2} \mathrm{~N}\right]^{-}$ & 0.00 & 0.00 & $-2.11 \mathrm{E}-07$ \\
\hline$[\mathrm{SCN}]^{-}$ & $-3.73 \mathrm{E}-04$ & $1.77 \mathrm{E}-04$ & $-6.30 \mathrm{E}-07$ \\
\hline$[\mathrm{eFAP}]^{-}$ & 0.002 & $9.57 \mathrm{E}-06$ & $-2.52 \mathrm{E}-07$ \\
\hline
\end{tabular}




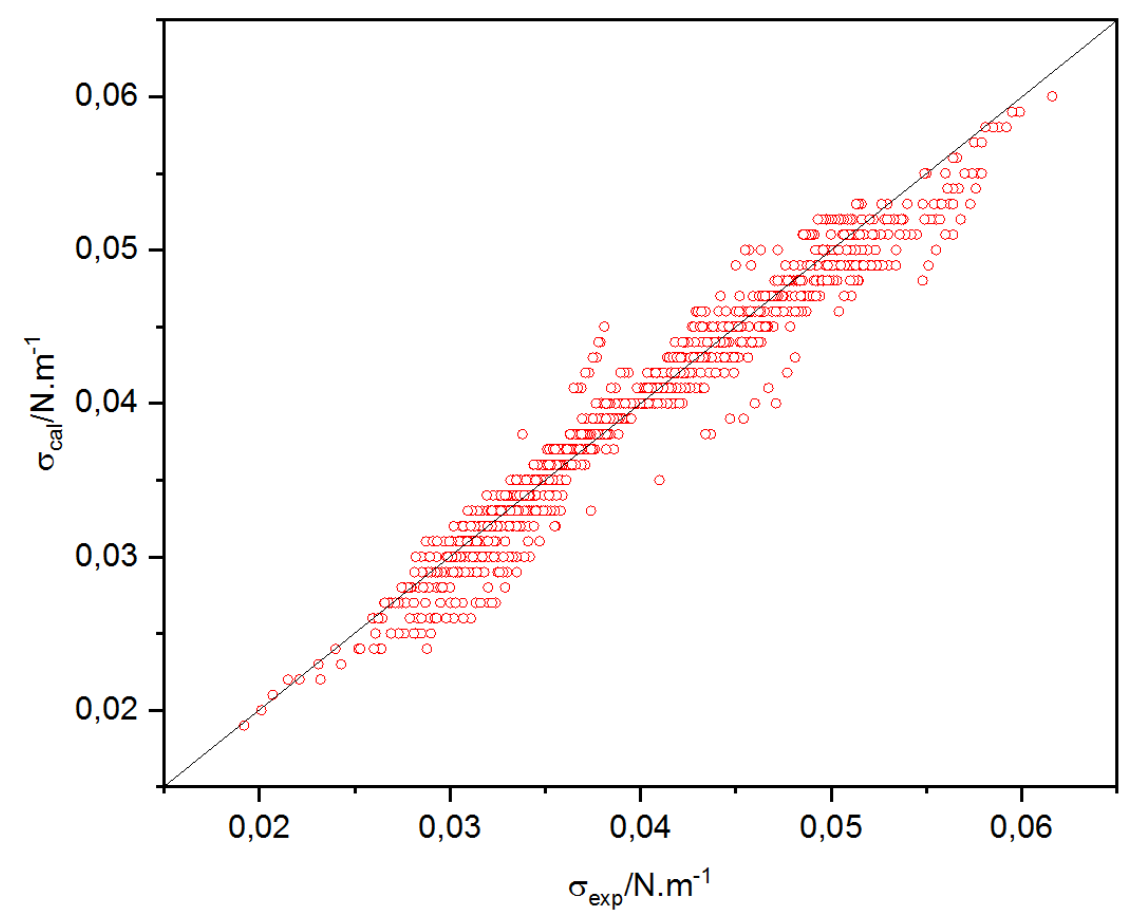

2

Figure A2. Comparison between experimental and calculated surface tension using estimation model, Eq.15

Parameters $C_{m \eta}(m=1,2,3,4,5)$ of viscosity in Eq.16 are obtained through the following group contribution method:

$$
C_{m \eta}=\sum_{i=1}^{k} n_{i} c_{i, m \eta}
$$

where $k$ is the total number of different groups in the molecule and $n_{i}$ denotes the number of groups of type $i$. Group contributions $c_{i, m \eta}(m=1,2,3,4,5)$ are regressed by fitting experimental data into Eq.16 using Eq.A7 as the objective function.

$$
O . F .=\frac{100 \times \sum_{i=1}^{N}\left|\left(\eta_{c a l}-\eta_{\exp }\right) / \eta_{\exp }\right|_{i}}{N}
$$

A number of 1842 data points for 86 ILs containing 8 cation cores, 18 anions and 3 substituents in the temperature range of $268.15-413.85 \mathrm{~K}$ are collected. The AARD $(\%)$ of this estimation model for viscosity is $5.1 \%$. The generated group contributions $c_{i, m \eta}$ are provided in Table A3 and comparison between experimental and calculated viscosity using this model are given in Figure A3.

Table A3: Regressed Group Contribution Parameters $c_{i, m \eta}(m=1,2,3,4,5)$ for Eq.A6 in the Temperature Range of 268.15-413.85 K

\begin{tabular}{lrrrrr}
\hline & $C_{1 \eta}(\mathrm{Pa} . \mathrm{s})$ & $C_{2 \eta}(\mathrm{Pa} . \mathrm{K} . \mathrm{K})$ & $C_{3 \eta}\left(\mathrm{Pa}_{\mathrm{s} . \mathrm{K}^{-1}}\right)$ & $C_{4 \eta}\left(\mathrm{Pa} . \mathrm{s} . \mathrm{K}^{-2}\right)$ & $C_{5 \eta}\left(\mathrm{Pa} . \mathrm{s} . \mathrm{K}^{2}\right)$ \\
\hline Substituents & & & & & \\
$\mathrm{CH}_{3}$ & -0.754 & -1.846 & 0.187 & $-2.25 \mathrm{E}-06$ & -0.005 \\
$\mathrm{CH}_{2}$ & 1.957 & 2.09 & -0.309 & $-6.06 \mathrm{E}-07$ & -0.013 \\
$\mathrm{dmN}$ & 0.026 & -2.882 & 0.435 & $-2.26 \mathrm{E}-05$ & -0.018 \\
Cations & & & & & \\
1,3 -dmIm (+) & 1.18 & 0.747 & -0.077 & $1.16 \mathrm{E}-05$ & 0.069 \\
$1,2,3$-tmIm (+) & 0.354 & -3.198 & 0.495 & $-6.88 \mathrm{E}-06$ & -0.038 \\
\hline
\end{tabular}




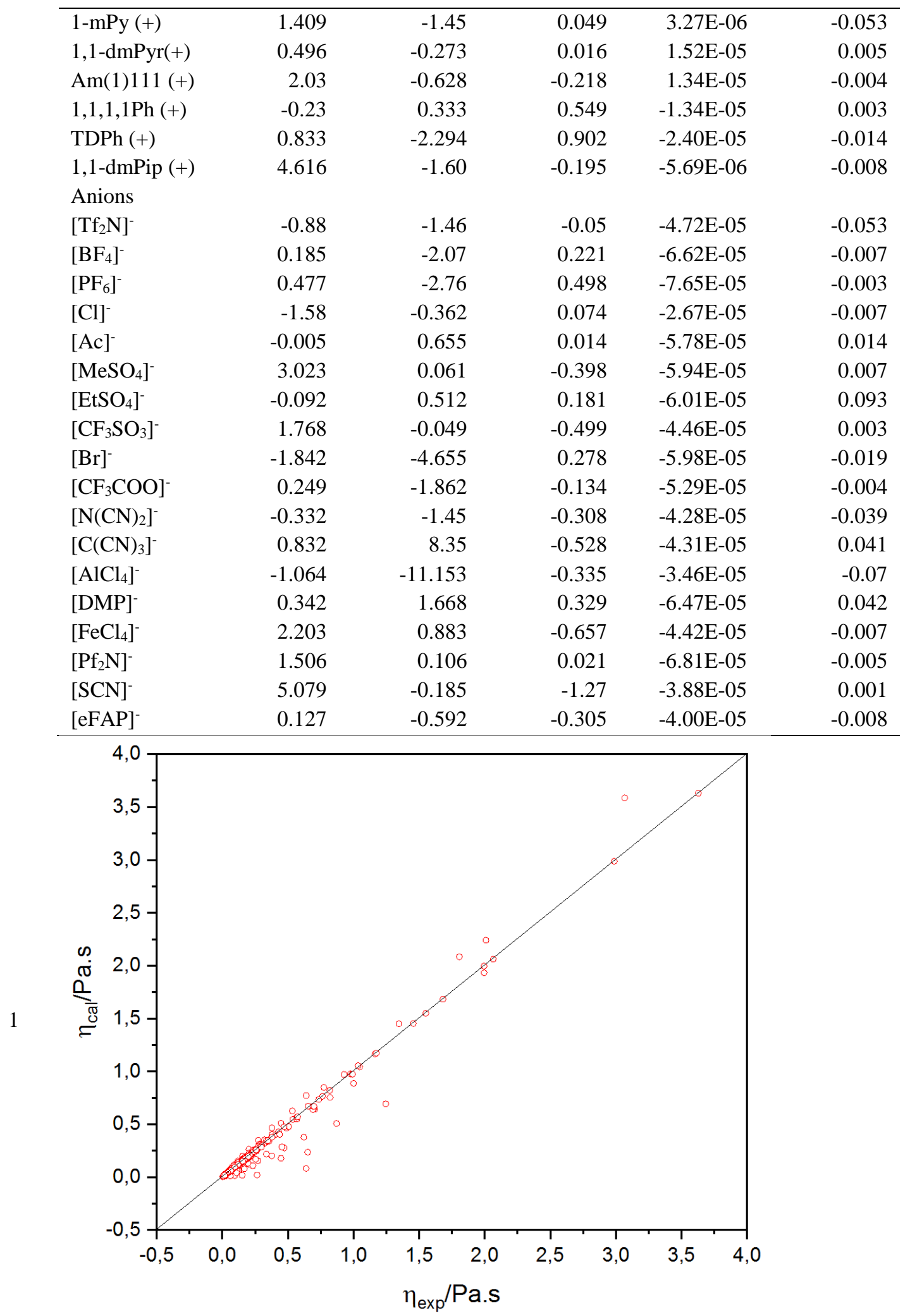

2 Figure A3. Comparison between experimental and calculated viscosity using estimation model, Eq.16 
As well as heat capacity, the values of parameters $C_{m \lambda}(m=4,5)$ for the thermal conductivity in Eq.17 are set to zero. A group contribution method (see Eq. A8) is used to calculate the remaining parameters $C_{m \lambda}(m=1,2,3)$.

$$
C_{m \lambda}=\sum_{i=1}^{k} n_{i} c_{i, m \lambda}
$$

where $k$ is the total number of different groups in the molecule and $n_{i}$ is the number of groups of type $i$. Group contributions $c_{i, m \lambda}(m=1,2,3)$ are obtained by the regression of experimental data into Eq.17 using Eq.A9 as the objective function.

$$
O . F .=\frac{100 \times \sum_{i=1}^{N}\left|\left(\lambda_{c a l}-\eta_{\text {exp }}\right) / \lambda_{\text {exp }}\right|_{i}}{N}
$$

A number of based on a number of 381 data points for 64 ILs involving 6 cation cores, 16 anions and 3 substituents in the temperature range of $273.15-390 \mathrm{~K}$ are considered. The AARD (\%) of this estimation model for viscosity is $2.6 \%$. The regressed group contributions $c_{i, m \lambda}$ are provided in Table A4 and comparison between experimental and calculated viscosity using this model are given in Figure A4.

14 Table A4: Regressed Group Contribution Parameters $c_{i, m \lambda}(m=1,2,3)$ for Eq.A8 in the

\begin{tabular}{|c|c|c|c|}
\hline & $c_{i, 1 \lambda}\left(\mathrm{W} \cdot \mathrm{m}^{-1} \cdot \mathrm{K}^{-1}\right)$ & $c_{i, 2 \lambda}\left(\mathrm{W} \cdot \mathrm{m}^{-1} \cdot \mathrm{K}^{-2}\right)$ & $c_{i, 3 \lambda}\left(\mathrm{W} \cdot \mathrm{m}^{-1} \cdot \mathrm{K}^{-3}\right)$ \\
\hline \multicolumn{4}{|l|}{ Substituents } \\
\hline $\mathrm{CH}_{3}$ & -0.047 & $3.50 \mathrm{E}-04$ & $-6.24 \mathrm{E}-07$ \\
\hline $\mathrm{CH}_{2}$ & -0.035 & $2.12 \mathrm{E}-04$ & $-3.37 \mathrm{E}-07$ \\
\hline $\mathrm{dmN}$ & -0.09 & $3.75 \mathrm{E}-04$ & $-1.92 \mathrm{E}-07$ \\
\hline \multicolumn{4}{|l|}{ Cations } \\
\hline 1,3-dmim $(+)$ & 0.195 & $-3.82 \mathrm{E}-04$ & $3.78 \mathrm{E}-05$ \\
\hline 1-mpy (+) & 0.347 & -0.001 & $3.85 \mathrm{E}-05$ \\
\hline 1,1-dmpyr (+) & 0.506 & -0.002 & 4.10E-05 \\
\hline Aml $1,1,1(+)$ & 0.845 & -0.004 & 4.38E-05 \\
\hline $\mathrm{Ph} 1,1,1,1(+)$ & 0.627 & -0.003 & $4.40 \mathrm{E}-06$ \\
\hline TDph (+) & 0.34 & -0.001 & $3.92 \mathrm{E}-05$ \\
\hline \multicolumn{4}{|l|}{ Anions } \\
\hline$\left[\mathrm{Tf}_{2} \mathrm{~N}\right]^{-}$ & 0.108 & $-6.74 \mathrm{E}-04$ & $-3.61 \mathrm{E}-05$ \\
\hline$\left[\mathrm{BF}_{4}\right]^{-}$ & -0.171 & 0.001 & $-3.86 \mathrm{E}-05$ \\
\hline$\left[\mathrm{PF}_{6}\right]^{-}$ & 0.149 & $-7.86 \mathrm{E}-04$ & $-3.60 \mathrm{E}-05$ \\
\hline$[\mathrm{Cl}]^{-}$ & -0.15 & 0.001 & $-3.92 \mathrm{E}-05$ \\
\hline$[\mathrm{Ac}]^{-}$ & -0.122 & 0.002 & $-4.00 \mathrm{E}-05$ \\
\hline$\left[\mathrm{MeSO}_{4}\right]^{-}$ & 0.119 & $-3.83 \mathrm{E}-04$ & $-3.66 \mathrm{E}-05$ \\
\hline$\left[\mathrm{EtSO}_{4}\right]^{-}$ & 0.763 & -0.005 & $-3.01 E-05$ \\
\hline$\left[\mathrm{CF}_{3} \mathrm{SO}_{3}\right]^{-}$ & -0.02 & $5.87 \mathrm{E}-04$ & $-3.80 \mathrm{E}-05$ \\
\hline$\left[\mathrm{CF}_{3} \mathrm{COO}\right]^{-}$ & -0.02 & $3.47 \mathrm{E}-04$ & $-3.77 \mathrm{E}-05$ \\
\hline$\left[\mathrm{N}(\mathrm{CN})_{2}\right]^{-}$ & 1.191 & -0.007 & $-2.69 \mathrm{E}-05$ \\
\hline$\left[\mathrm{C}(\mathrm{CN})_{3}\right]^{-}$ & 0.166 & $-5.67 \mathrm{E}-04$ & $-3.65 \mathrm{E}-05$ \\
\hline$[\mathrm{B}(\mathrm{CN}) 4]^{-}$ & 0.017 & $3.96 \mathrm{E}-04$ & $-3.81 \mathrm{E}-05$ \\
\hline$[\mathrm{DMP}]^{-}$ & -0.172 & -0.013 & $-1.30 \mathrm{E}-05$ \\
\hline$[\mathrm{DEP}]^{-}$ & 2.174 & 0.00 & $-1.84 \mathrm{E}-05$ \\
\hline$[\mathrm{SCN}]^{-}$ & -0.02 & $5.87 \mathrm{E}-04$ & $-3.80 \mathrm{E}-05$ \\
\hline [eFAP $^{-}$ & -0.172 & 0.001 & $-3.89 \mathrm{E}-05$ \\
\hline
\end{tabular}
15 Temperature Range of 273.15-390 K 


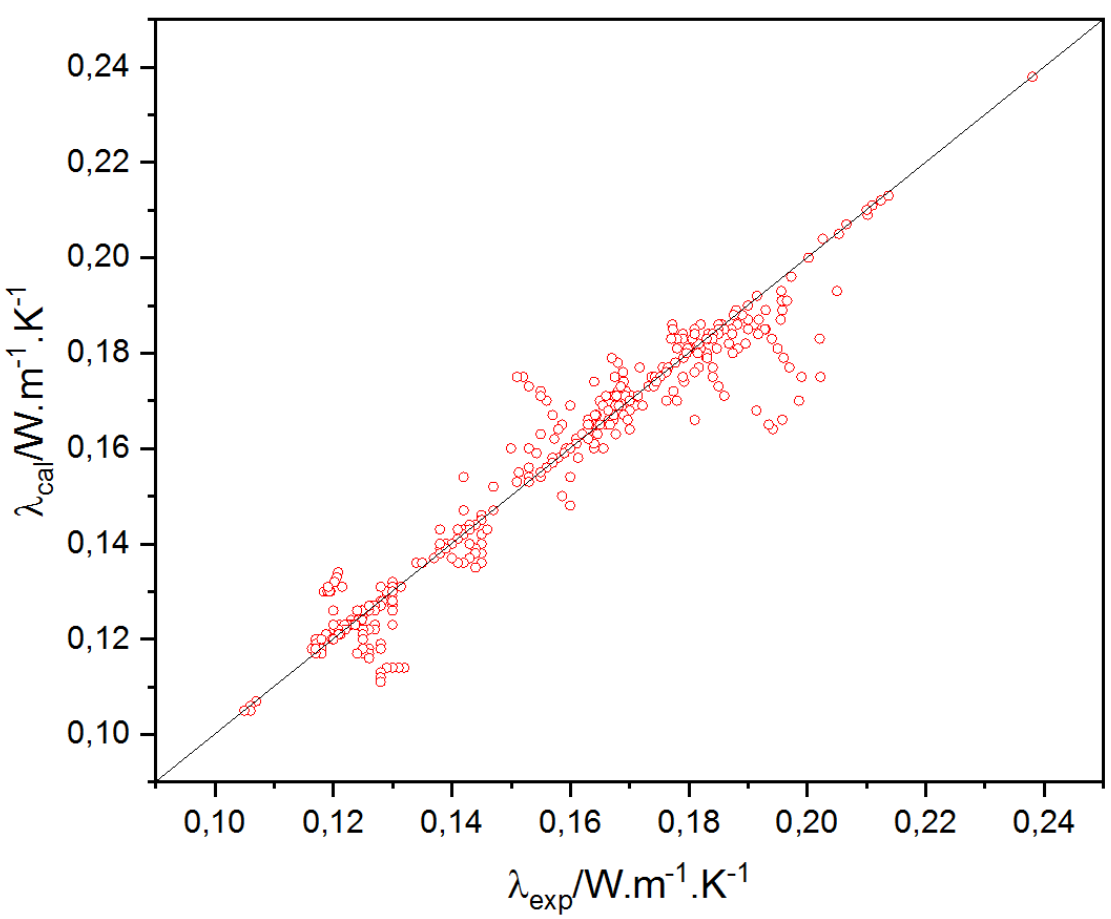

2 Figure A4. Comparison between experimental and calculated thermal conductivity using estimation 3 model, Eq.17

4 A summary of property estimation of ILs using GC methods for these empirical equations extracted 5 from Aspen plus is given in Table A5, where the number of regressed data points and the AARD\% 6 of each family of cation-based ILs as well as all families for the four properties are provided.

$7 \quad$ Table A5. Summary of Property Estimation of ILs using Sub-models Extracted from Aspen Plus

\begin{tabular}{llll}
\hline Properties & Cation-based & Data points & $\begin{array}{l}\text { Average Absolute } \\
\text { Relative Deviation (\%) }\end{array}$ \\
\hline \multirow{4}{*}{ Heat capacity } & Imidazolium- & 1233 & 0.61 \\
(Eq.19) & Pyridinium- & 442 & 0.81 \\
& Pyrrolidinium- & 102 & 1.25 \\
& Alkyl ammonium- & 31 & 0.2 \\
& Phosphonium- & 191 & 0.81 \\
& Piperidinium- & 23 & 0.09 \\
& All families & $\mathbf{2 0 2 2}$ & $\mathbf{0 . 7}$ \\
\cline { 2 - 4 } Surface tension & Imidazolium- & 940 & 3.63 \\
(Eq.23) & Pyridinium- & 281 & 2.90 \\
& Pyrrolidinium- & 130 & 2.25 \\
& Alkyl ammonium- & 111 & 3.47 \\
& Phosphonium- & 94 & 5.66 \\
& Piperidinium- & 21 & 0.34 \\
& All families & $\mathbf{1 5 7 7}$ & $\mathbf{3 . 4}$ \\
\cline { 2 - 3 } Viscosity & Imidazolium- & 1028 & 5.87 \\
(Eq.26) & Pyridinium- & 280 & 4.66 \\
& Pyrrolidinium- & 76 & 5.10 \\
& Alkyl ammonium- & 149 & 4.77 \\
& Phosphonium- & 253 & 2.85 \\
\hline
\end{tabular}




\begin{tabular}{llll}
\hline & Piperidinium- & 56 & 4.12 \\
& All families & $\mathbf{1 8 4 2}$ & $\mathbf{5 . 1}$ \\
\cline { 2 - 4 } Thermal & Imidazolium- & 309 & 2.94 \\
conductivity & Pyridinium- & 15 & 1.29 \\
(Eq.29) & Pyrrolidinium- & 16 & 1.55 \\
& Alkyl ammonium- & 9 & 0.47 \\
& Phosphonium- & 32 & 0.82 \\
& All families & $\mathbf{3 8 1}$ & $\mathbf{2 . 4}$ \\
\hline
\end{tabular}

\section{Supplementary material}

Tables summarizing the information of the experimental data collected in this work. These data are used to regressed the corresponding parameters of sub-models for calculating temperature-dependent properties (heat capacity, surface tension, viscosity and thermal conductivity) required in the process simulation in Aspen Plus.

\section{References}

ANANTHARAJ, R. \& BANERJEE, T. 2010. COSMO-RS-based screening of ionic liquids as green solvents in denitrification studies. Industrial \& Engineering Chemistry Research, 49, 8705-8725.

BABI, D. K., HOLTBRUEGGE, J., LUTZE, P., G RAK, A., WOODLEY, J. M. \& GANI, R. 2015. Sustainable process synthesis-intensification. Computers \& Chemical Engineering, 81, 218-244.

BONDI, A. 1964. van der Waals volumes and radii. The Journal of physical chemistry, 68, 441-451.

CABALLERO, J. A., GROSSMANN, I. E., KEYVANI, M. \& LENZ, E. S. 2009. Design of hybrid distillationvapor membrane separation systems. Industrial \& engineering chemistry research, 48, 9151-9162.

CHEN, Y., WOODLEY, J., KONTOGEORGIS, G. \& GANI, R. 2018. Integrated Ionic Liquid and Process Design involving Hybrid Separation Schemes. Computer Aided Chemical Engineering, 44, 1045-1050.

CHEN, Y., GANI, R., KONTOGEORGIS, G. \& WOODLEY, J. 2019a. Integrated ionic liquid and process design involving azeotropic separation processes. Chemical Engineering Science, 203, 402-414.

CHEN, Y., KONTOGEORGIS, G. \& WOODLEY, J. 2019b. Group contribution-based estimation method for properties of ionic liquids. Industrial \& Engineering Chemistry Research, 58, 4277-4292.

CHONG, F. K., ELJACK, F. T., ATILHAN, M., FOO, D. C. \& CHEMMANGATTUVALAPPIL, N. G. 2016. A systematic visual methodology to design ionic liquids and ionic liquid mixtures: Green solvent alternative for carbon capture. Computers \& Chemical Engineering, 91, 219-232.

CHONG, F. K., FOO, D. C., ELJACK, F. T., ATILHAN, M. \& CHEMMANGATTUVALAPPIL, N. G. 2015. Ionic liquid design for enhanced carbon dioxide capture by computer-aided molecular design approach. Clean Technologies and Environmental Policy, 17, 1301-1312.

COLQUHOUN, H., THOMPSON, D. J., \& TWIGG, M. 1991. Synthesis of aldehydes. In Carbonylation (pp. 5568). Springer US.

DAI, C., LEI, Z., WANG, W., XIAO, L. \& CHEN, B. 2013. Group contribution lattice fluid equation of state for CO2-ionic liquid systems: an experimental and modeling study. AIChE Journal, 59, 4399-4412.

DAVIS, J. C., VALUS, R. J., ESHRAGHI, R. \& VELIKOFF, A. E. 1993. Facilitated transport membrane hybrid systems for olefin purification. Separation science and technology, 28, 463-476.

DIEDENHOFEN, M., KLAMT, A., MARSH, K. \& SCH FER, A. 2007. Prediction of the vapor pressure and vaporization enthalpy of 1-n-alkyl-3-methylimidazolium-bis-(trifluoromethanesulfonyl) amide ionic liquids. Physical Chemistry Chemical Physics, 9, 4653-4656

DRIOLI, E., STANKIEWICZ, A. I. \& MACEDONIO, F. 2011. Membrane engineering in process intensification-An overview. Journal of Membrane Science, 380, 1-8.

EIKE, D. M., BRENNECKE, J. F. \& MAGINN, E. J. 2004. Predicting infinite-dilution activity coefficients of organic solutes in ionic liquids. Industrial \& Engineering Chemistry Research, 43, 1039-1048.

FARAHIPOUR, R., MEHRKESH, A. \& KARUNANITHI, A. T. 2016. A systematic screening methodology towards exploration of ionic liquids for CO 2 capture processes. Chemical Engineering Science, 145, 126-132.

FEDOROVA, M., SIN, G. \& GANI, R. 2015. Computer-aided modelling template: Concept and application. Computers \& Chemical Engineering, 83, 232-247.

FR BA, A., RAUSCH, M., KRZEMINSKI, K., ASSENBAUM, D., WASSERSCHEID, P. \& LEIPERTZ, A. 2010. Thermal conductivity of ionic liquids: measurement and prediction. International Journal of Thermophysics, 31, 2059-2077.

GANI, R., HYTOFT, G., JAKSLAND, C. \& JENSEN, A. K. 1997. An integrated computer aided system for integrated design of chemical processes. Computers \& Chemical Engineering, 21, 1135-1146. 
GANI, R., NIELSEN, B. \& FREDENSLUND, A. 1991. A group contribution approach to computer - aided molecular design. AIChE Journal, 37, 1318-1332.

GARDAS, R. L. \& COUTINHO, J. A. 2009. Group contribution methods for the prediction of thermophysical and transport properties of ionic liquids. AIChE Journal, 55, 1274-1290.

GE, R., HARDACRE, C., JACQUEMIN, J., NANCARROW, P. \& ROONEY, D. W. 2008. Heat capacities of ionic liquids as a function of temperature at $0.1 \mathrm{MPa}$. Measurement and prediction. Journal of Chemical \& Engineering Data, 53, 2148-2153.

GOLDBLATT, M. \& GOODING, C. An engineering analysis of membrane-aided distillation. AIChE Symp. Ser, 1986. 51-69.

GUERRERO, H., MART N, S., P REZ-GREGORIO, V., LAFUENTE, C. \& BANDR S, I. 2012. Volumetric characterization of pyridinium-based ionic liquids. Fluid Phase Equilibria, 317, 102-109.

GUTIÉRREZ, J. P., MEINDERSMA, G. W. \& DE HAAN, A. B. 2012. COSMO-RS-based ionic-liquid selection for extractive distillation processes. Industrial \& Engineering Chemistry Research, 51, 11518-11529.

HECTOR, T. \& GMEHLING, J. 2014. Present status of the modified UNIFAC model for the prediction of phase equilibria and excess enthalpies for systems with ionic liquids. Fluid Phase Equilibria, 371, 82-92.

HEINTZ, A., VEREVKIN, S. P. \& ONDO, D. 2006. Thermodynamic properties of mixtures containing ionic liquids. 8. Activity coefficients at infinite dilution of hydrocarbons, alcohols, esters, and aldehydes in 1-hexyl-3-methylimidazolium bis (trifluoromethylsulfonyl) imide using gas- liquid chromatography. Journal of Chemical \& Engineering Data, 51, 434-437.

HOLBREY, J. \& SEDDON, K. 1999. Ionic liquids. Clean Technologies and Environmental Policy, 1, 223-236. https://www.britannica.com/science/aldehyde, accessed on 08 Jan 2019

HUANG, Y., DONG, H., ZHANG, X., LI, C. \& ZHANG, S. 2013. A new fragment contribution - corresponding states method for physicochemical properties prediction of ionic liquids. AIChE Journal, 59, 13481359.

JACQUEMIN, J., HUSSON, P., PADUA, A. A. \& MAJER, V. 2006. Density and viscosity of several pure and water-saturated ionic liquids. Green Chemistry, 8, 172-180.

KARUNANITHI, A. T. \& MEHRKESH, A. 2013. Computer - aided design of tailor - made ionic liquids. AIChE Journal, 59, 4627-4640.

KLAMT, A. 1995. Conductor-like screening model for real solvents: a new approach to the quantitative calculation of solvation phenomena. The Journal of Physical Chemistry, 99, 2224-2235.

KLAMT, A. \& ECKERT, F. 2000. COSMO-RS: a novel and efficient method for the a priori prediction of thermophysical data of liquids. Fluid Phase Equilibria, 172, 43-72.

KLAMT, A., JONAS, V., B RGER, T. \& LOHRENZ, J. C. 1998. Refinement and parametrization of COSMORS. The Journal of Physical Chemistry A, 102, 5074-5085.

KOLLER, T., RAUSCH, M. H., SCHULZ, P. S., BERGER, M., WASSERSCHEID, P., ECONOMOU, I. G., LEIPERTZ, A. \& FRÖBA, A. P. 2012. Viscosity, interfacial tension, self-diffusion coefficient, density, and refractive index of the ionic liquid 1-ethyl-3-methylimidazolium tetracyanoborate as a function of temperature at atmospheric pressure. Journal of Chemical \& Engineering Data, 57, 828-835.

KUMAR, A. A. P. \& BANERJEE, T. 2009. Thiophene separation with ionic liquids for desulphurization: A quantum chemical approach. Fluid Phase Equilibria, 278, 1-8.

LEE, B.-S. \& LIN, S.-T. 2015. Screening of ionic liquids for CO2 capture using the COSMO-SAC model. Chemical Engineering Science, 121, 157-168.

LEI, Z., CHEN, B. \& LI, C. 2007. COSMO-RS modeling on the extraction of stimulant drugs from urine sample by the double actions of supercritical carbon dioxide and ionic liquid. Chemical engineering science, 62, 3940-3950.

LEI, Z., DAI, C. \& CHEN, B. 2013. Gas solubility in ionic liquids. Chemical reviews, 114, 1289-1326.

LEI, Z., DAI, C., LIU, X., XIAO, L. \& CHEN, B. 2012a. Extension of the UNIFAC model for ionic liquids. Industrial \& Engineering Chemistry Research, 51, 12135-12144.

LEI, Z., DAI, C., WANG, W. \& CHEN, B. 2014a. UNIFAC model for ionic liquid - CO2 systems. AIChE Journal, 60, 716-729.

LEI, Z., DAI, C., ZHU, J. \& CHEN, B. 2014b. Extractive distillation with ionic liquids: a review. AIChE Journal, 60, 3312-3329.

LEI, Z., XIAO, L., DAI, C. \& CHEN, B. 2012b. Group contribution lattice fluid equation of state (GCLF EOS) for ionic liquids. Chemical engineering science, 75, 1-13.

LEI, Z., ZHANG, J., LI, Q. \& CHEN, B. 2009. UNIFAC model for ionic liquids. Industrial \& Engineering Chemistry Research, 48, 2697-2704.

LIESE, A., SEELBACH, K. \& WANDREY, C. 2006. Industrial biotransformations, John Wiley \& Sons.

LIN, S.-T., CHANG, J., WANG, S., GODDARD, W. A. \& SANDLER, S. I. 2004. Prediction of vapor pressures and enthalpies of vaporization using a COSMO solvation model. The Journal of Physical Chemistry A, 108, 7429-7439.

LIN, S.-T. \& SANDLER, S. I. 2002. A priori phase equilibrium prediction from a segment contribution solvation model. Industrial \& engineering chemistry research, 41, 899-913. 
LUTZE, P., GANI, R. \& WOODLEY, J. M. 2010. Process intensification: a perspective on process synthesis. Chemical Engineering and Processing: Process Intensification, 49, 547-558.

MART NEZ-ARAG N, M., BURGHOFF, S., GOETHEER, E. \& DE HAAN, A. 2009. Guidelines for solvent selection for carrier mediated extraction of proteins. Separation and Purification Technology, 65, 6572.

MOGANTI, S., NOBLE, R. D. \& KOVAL, C. A. 1994. Analysis of a membrane/distillation column hydrid process. Journal of membrane science, 93, 31-44.

MOUSAZADEH, M. \& FARAMARZI, E. 2011. Corresponding states theory for the prediction of surface tension of ionic liquids. Ionics, 17, 217-222.

PADUSZYNSKI, K. \& DOMANSKA, U. 2011. A new group contribution method for prediction of density of pure ionic liquids over a wide range of temperature and pressure. Industrial \& Engineering Chemistry Research, 51, 591-604.

PADUSZYNSKI, K., LUKOSHKO, E. V., KR LIKOWSKI, M., DOMANSKA, U. \& SZYDŁOWSKI, J. 2015. Thermodynamic study of binary mixtures of 1-butyl-1-methylpyrrolidinium dicyanamide ionic liquid with molecular solvents: new experimental data and modeling with PC-SAFT equation of state. The Journal of Physical Chemistry B, 119, 543-551.

PALOMAR, J., FERRO, V. R., TORRECILLA, J. S. \& RODR GUEZ, F. 2007. Density and molar volume predictions using COSMO-RS for ionic liquids. An approach to solvent design. Industrial \& Engineering Chemistry Research, 46, 6041-6048.

PALOMAR, J., GONZALEZ-MIQUEL, M., POLO, A. \& RODRIGUEZ, F. 2011. Understanding the physical absorption of $\mathrm{CO} 2$ in ionic liquids using the COSMO-RS method. Industrial \& Engineering Chemistry Research, 50, 3452-3463.

PAPADAKIS, E., TULA, A. K. \& GANI, R. 2016. Solvent selection methodology for pharmaceutical processes: Solvent swap. Chemical Engineering Research and Design, 115, 443-461.

PELlEGRINO, J.L., MARGOLIS, N., JUSTINIANO, M., MILLER, M. \& THEDKI, A. 2004. Energy Use, Lossand Opportunities Analysis: US Manufacturing and Mining, DOE/ITP (U.S. Dep.Energy's Iindustrial Technol. Program) 169.

PETTERSEN, T., ARGO, A., NOBLE, R. D. \& KOVAL, C. A. 1996. Design of combined membrane and distillation processes. Separations Technology, 6, 175-187.

RAUTENBACH, R. \& ALBRECHT, R. 1985. The separation potential of pervaporation: Part 2. Process design and economics. Journal of Membrane Science, 25, 25-54.

ROUGHTON, B. C., CHRISTIAN, B., WHITE, J., CAMARDA, K. V. \& GANI, R. 2012. Simultaneous design of ionic liquid entrainers and energy efficient azeotropic separation processes. Computers \& Chemical Engineering, 42, 248-262.

SANTIAGO, R. S., SANTOS, G. R. \& AZNAR, M. 2009. UNIQUAC correlation of liquid-liquid equilibrium in systems involving ionic liquids: The DFT-PCM approach. Fluid Phase Equilibria, 278, 54-61.

SANTIAGO, R. S., SANTOS, G. R. \& AZNAR, M. 2010a. Liquid-liquid equilibrium in ternary ionic liquid systems by UNIFAC: New volume, surface area and interaction parameters. Part I. Fluid Phase Equilibria, 295, 93-97.

SANTIAGO, R., SANTOS, G. \& AZNAR, M. 2010b. Liquid-liquid equilibrium in ternary ionic liquid systems by UNIFAC: new volume, surface area and interaction parameters. Fluid Phase Equilib, 295, 93-97.

SEILER, M., JORK, C., KAVARNOU, A., ARLT, W. \& HIRSCH, R. 2004. Separation of azeotropic mixtures using hyperbranched polymers or ionic liquids. AIChE Journal, 50, 2439-2454.

SHOLL, D. S. \& LIVELY, R. P. 2016. Seven chemical separations: to change the world: purifying mixtures without using heat would lower global energy use, emissions and pollution--and open up new routes to resources. Nature, 532, 435-438.

SIMONI, L. D., LIN, Y., BRENNECKE, J. F. \& STADTHERR, M. A. 2008. Modeling liquid- liquid equilibrium of ionic liquid systems with NRTL, electrolyte-NRTL, and UNIQUAC. Industrial \& Engineering Chemistry Research, 47, 256-272.

SMITH, M. B., \& MARCH, J. 2006. March's Advanced Organic Chemistry: Reactions, Mechanisms and Structure, 6th Edition. Wiley.

SONG, Z., ZHANG, C., QI, Z., ZHOU, T. \& SUNDMACHER, K. 2018. Computer - aided design of ionic liquids as solvents for extractive desulfurization. AIChE Journal, 64, 1013-1025.

STEPHAN, W., NOBLE, R. D. \& KOVAL, C. A. 1995. Design methodology for a membrane/distillation column hybrid process. Journal of Membrane Science, 99, 259-272.

SUN, N., HE, X., DONG, K., ZHANG, X., LU, X., HE, H. \& ZHANG, S. 2006. Prediction of the melting points for two kinds of room temperature ionic liquids. Fluid phase equilibria, 246, 137-142.

TOFTGAARD PEDERSEN, A., BIRMINGHAM, W. R., REHN, G., CHARNOCK, S. J., TURNER, N. J. \& WOODLEY, J. M. 2015. Process requirements of galactose oxidase catalyzed oxidation of alcohols. Organic Process Research \& Development, 19, 1580-1589.

TORRECILLA, J. S., PALOMAR, J., GARCÍA, J. N. \& RODRÍGUEZ, F. 2009. Effect of cationic and anionic chain lengths on volumetric, transport, and surface properties of 1-alkyl-3-methylimidazolium 

alkylsulfate ionic liquids at (298.15 and 313.15) K. Journal of Chemical \& Engineering Data, 54, 1297 1301.

TROHALAKI, S., PACHTER, R., DRAKE, G. W. \& HAWKINS, T. 2005. Quantitative structure- property relationships for melting points and densities of ionic liquids. Energy \& Fuels, 19, 279-284.

TULA, A. K., BEFORT, B., GARG, N., CAMARDA, K. V. \& GANI, R. 2016. Sustainable process design \& analysis of hybrid separations. Computers \& Chemical Engineering, 105, 96-104.

VALDERRAMA, J. O. \& ZARRICUETA, K. 2009. A simple and generalized model for predicting the density of ionic liquids. Fluid Phase Equilibria, 275, 145-151.

VALENCIA-MARQUEZ， D., FLORES-TLACUAHUAC， A. \& VASQUEZ-MEDRANO, R. 2011. Simultaneous optimal design of an extractive column and ionic liquid for the separation of bioethanolwater mixtures. Industrial \& Engineering Chemistry Research, 51, 5866-5880.

VAN HECKE, W., KAUR, G. \& DE WEVER, H. 2014. Advances in in-situ product recovery (ISPR) in whole cell biotechnology during the last decade. Biotechnology advances, 32, 1245-1255.

WHITTAKER, J. W. 2003. Free radical catalysis by galactose oxidase. Chemical Reviews, 103, $2347-2364$.

WITTIG, R., LOHMANN, J. \& GMEHLING, J. 2003. Vapor- liquid equilibria by UNIFAC group contribution. 6. Revision and extension. Industrial \& engineering chemistry research, 42, 183-188.

WOODLEY, J. M. 2017. Bioprocess intensification for the effective production of chemical products. Computers \& Chemical Engineering, 105, 297-307.

WOODLEY, J. M., BISSCHOPS, M., STRAATHOF, A. J. \& OTTENS, M. 2008. Future directions for in - situ product removal (ISPR). Journal of chemical technology and biotechnology, 83, 121-123. 